\title{
6. FLUVIODELTAIC SUCCESSIONS AT THE WOMBAT PLATEAU: UPPER TRIASSIC SILICICLASTIC-CARBONATE CYCLES ${ }^{1}$
}

\author{
Makoto Ito, ${ }^{2}$ Suzanne O'Connell, ${ }^{3}$ Ann Stefani, ${ }^{4}$ and Peter Borella ${ }^{5}$
}

\begin{abstract}
The Carnian to Norian sediments, as much as $600 \mathrm{~m}$ in total thickness, recovered from ODP Sites 759 and 760 on the Wombat Plateau, are generally represented by fluvial-dominated deltaic successions.

In general, the Carnian to Norian sandstones are quartzose. The average ratio of monocrystalline quartz grains, total feldspar grains, and total lithic fragments (i.e., Qm:F:Lt ratio) is 71:22:7. This indicates that they were derived mainly from the transitional continental and cratonic interior provenance terranes, such as the Pilbara Precambrian block to the south of the Wombat Plateau. The upper Carnian sediments, however, are characterized by more feldspathic sandstone petrofacies. They typically contain some volcanic rock fragments with trachytic texture and indicate the onset of the incipient rift-related tectonic movement, such as uplift and subsequent abrupt basin subsidence, together with volcanism in the Gondwana continental block.

Mixed siliciclastic and carbonate cycles are typically intercalated in the prodelta to delta front deposits that developed mainly in a lagoon-like, restricted marine environment. The restricted marine environment developed during transgressions as the outflow of shallow water was restricted by depositional barriers. Around the barriers and/or delta lobes, carbonate shoals/banks were probably developed and the allochemical components of the neritic limestones may have been transported into the restricted marine environment by overwash processes and/or storm waves. Siliciclastic detritus, on the other hand, was mainly derived accompanied by delta progradation dominated by fluvial processes in the restricted marine environment. Therefore, we interpret the mixed siliciclastic and carbonate cycles in the deltaic successions to be a result of transgression-regression cycles in a deltaic system during the Late Triassic.
\end{abstract}

\section{INTRODUCTION}

During Ocean Drilling Program (ODP) Leg 122, Sites 759, 760,761 , and 764 were drilled on the Wombat Plateau, the northern precinct of the Exmouth Plateau (Fig. 1). Upper Triassic siliciclastic and carbonate rocks, as much as $1100 \mathrm{~m}$ in total thickness, were recovered. The Carnian to Norian successions recovered from Sites 759 and 760 are represented mainly by deltaic successions intercalated with neritic limestones. In contrast, neritic and reefal limestones are dominant in the Rhaetian successions (Sites 761 and 764), together with some crinoidal limestones at the base and top of the successions (Fig. 2).

Mixed siliciclastic and carbonate sediments, as recovered from Sites 759 and 760 , have recently received much attention about their depositional environments and formative processes, mainly in terms of sea-level change and tectonic movement of the sedimentary basins (e.g., Walker et al., 1983; Driese and Dott, 1984; Mount, 1984; Sarg, 1988; Dolan, 1989; Yose and Heller, 1989). The Carnian to Norian deltaic successions documented at Sites 759 and 760 are good examples of a mixed siliciclastic and carbonate depositional system developed in a marginal marine environment at an incipient passive continental margin where simple tectonic subsidence may have generally prevailed.

\footnotetext{
1 von Rad, U., Haq, B. U., et al., 1992. Proc. ODP, Sci. Results, 122: College Station, TX (Ocean Drilling Program).

${ }^{2}$ Geological Institute, College of Arts and Sciences, Chiba University, Chiba 260, Japan.

${ }^{3}$ Department of Earth and Environmental Sciences, Wesleyan University, Middletown, CT 06457, U.S.A.

${ }^{4}$ Department of Geology, California State University, Fullerton, CA 92634 , U.S.A.

5 Saddleback College, 28000 Marguerite Parkway, Mission Viejo, CA 92692, U.S.A.
}

The major purpose of this paper is to describe the depositional facies and petrofacies of the Carnian to Norian deltaic sediments recovered from Sites 759 and 760 and to document their temporal changes in terms of sea-level fluctuations and paleotectonics of provenance terranes. In addition, we discuss possible formative processes of the mixed siliciclastic and carbonate cycles developed in the deltaic successions.

\section{REGIONAL TECTONIC SETTING}

The Exmouth and Wombat plateaus (Fig. 1) are included in the numerous basins and sub-basins of the Westralian Superbasin that extends from the continent to the $4000-\mathrm{m}$ isobath. The Wombat Plateau is a northward-tilted block or horst in the northern precinct of the Exmouth Plateau and is separated from the Exmouth Plateau by the Wombat half-graben, which formed during the Callovian in the northern Exmouth Plateau area and the late Neocomian at the central Exmouth Plateau (Exon et al., this volume, chapter 1; von Rad et al., this volume).

The Exmouth Plateau is $600 \mathrm{~km}$ long by $350 \mathrm{~km}$ wide, with water depths ranging from 800 to $4000 \mathrm{~m}$, and is a rifted and deeply subsided piece of continental crust, which is covered by more than $8 \mathrm{~km}$ of Phanerozoic sediments in response to the breakup of the Gondwanaland. The Exmouth Plateau is bounded on the north and south by the Argo and Cuvier abyssal plains and on the west by the Gascoyne Abyssal Plain. The northern and western margins of the Exmouth Plateau are defined by an extensional tectonic regime, related to the rifting and the subsequent development of the oceanic crust. In contrast, the southern margin formed in a transform tectonic regime. The northern Exmouth Plateau margin separated from a continental fragment to the north in the late Berriasian (approximately $140 \mathrm{Ma}$ ) and the western margin developed during the late Valanginian (approximately $135 \mathrm{Ma}$ ) (Ludden, Gradstein, et al., 1990). Detailed interpretations of the tectonic development of the Exmouth and Wombat plateaus have 

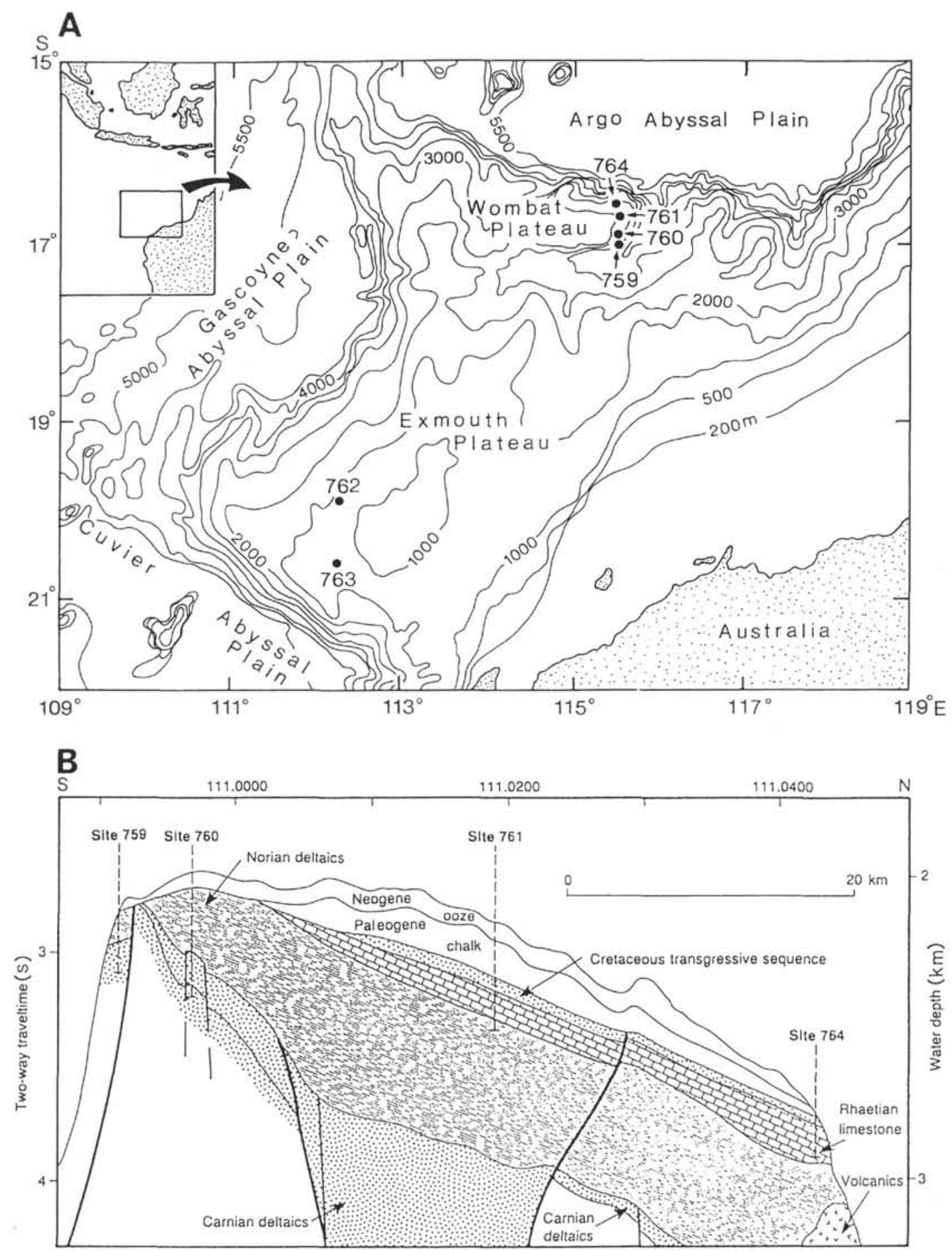

Figure 1. A. Bathymetric map of the Exmouth and Wombat plateau regions (modified from Haq, von Rad, O'Connell, et al., 1990). B. Geological interpretation of Wombat Plateau showing the Leg 122 site locations (modified from Haq, von Rad, O'Connell, et al., 1990).

been given elsewhere (Veevers, 1988; Mutter et al., 1989; von Rad et al., 1989; Exon et al., this volume, chapter 1; Williamson, this volume; Haq et al., this volume).

\section{REGIONAL DEPOSITIONAL SETTING}

The Phanerozoic sediments developed in the Wombat and Exmouth plateaus are as much as $8 \mathrm{~km}$ thick, ranging from Permian through Quaternary. The upper 1-2 km of sediment was deposited after the breakup of Gondwanaland (Exon and Willcox, 1980; von Rad and Exon, 1983).

The older clastic sediments were derived mainly from the southern hinterlands and were deposited until the Neocomian. The Permian to Middle Jurassic sediments, about $5 \mathrm{~km}$ thick, were deposited in fluviodeltaic, paralic, and shallow-marine environments that developed along a Neo-Tethyan embayment of eastern Gondwanaland. The overlying Neocomian 


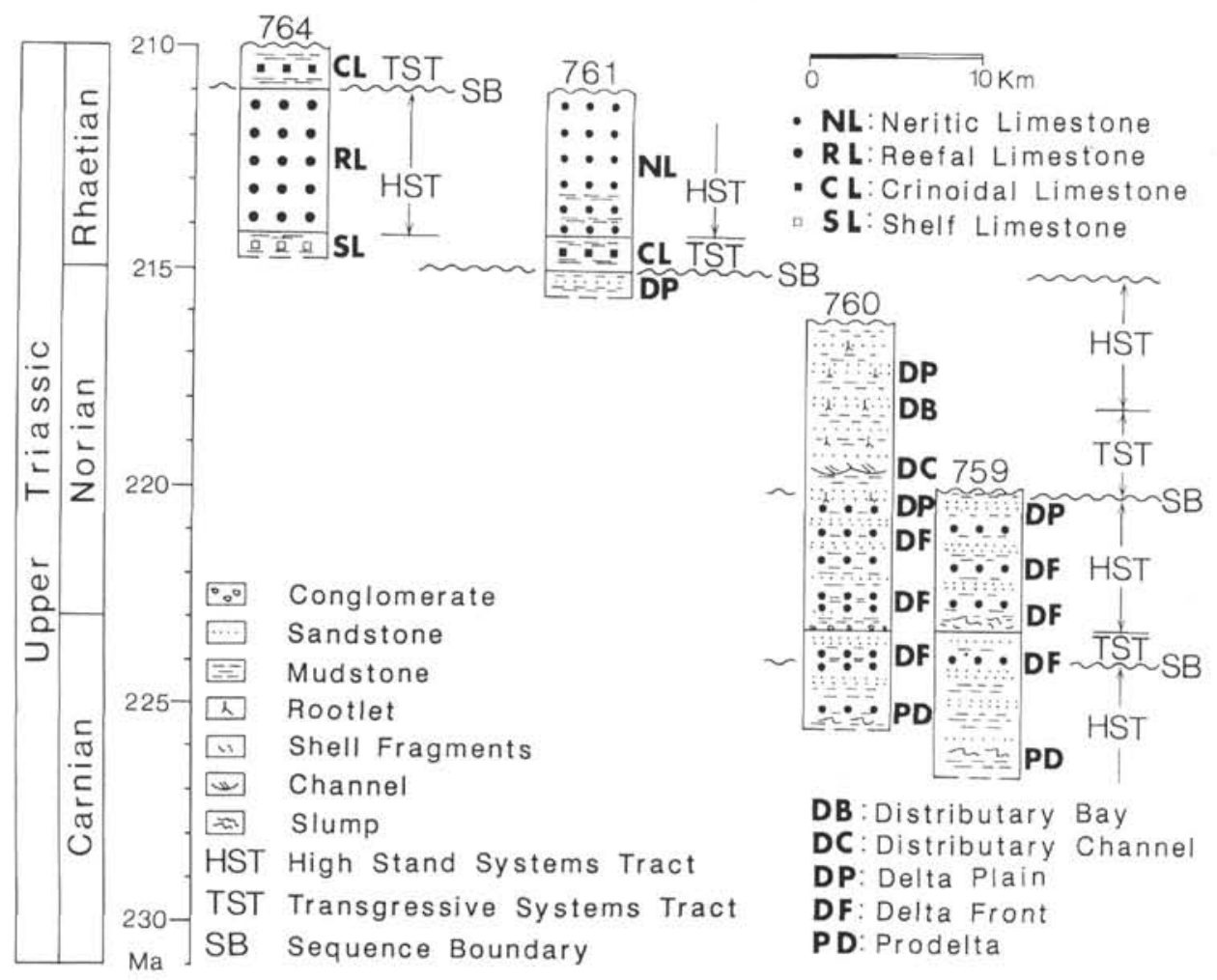

Figure 2. Upper Triassic sediments recovered from Leg 122 sites on the Wombat Plateau. Sequence stratigraphy from Haq et al. (this volume) and von Rad et al. (this volume).

sediments, up to $2 \mathrm{~km}$ thick, were deposited in delta and prodelta environments following the Jurassic rifting and draped the Late Jurassic and Neocomian block-faulted surfaces (Haq et al., 1988).

The younger sediments, about $1 \mathrm{~km}$ thick, are represented mainly by hemipelagic and pelagic chalk, marl, and ooze, except for the Aptian black shale and claystone of a restricted shelf environment origin. After the Aptian, siliciclastic influences decreased in response to the development of transgressive and highstand systems tracts (Haq et al., 1988) (Fig. 1). The open marine conditions that prevailed through the remainder of the Cretaceous and Cenozoic indicate the development of a terrigenous sediment-starved, passive continental margin.

\section{DEPOSITIONAL FACIES}

The Carnian and Norian sediments recovered from the Wombat Plateau are described from core sections and core photographs. They show an overall shallowing-upward sequence and are characterized by mixed siliciclastic and carbonate cycles (Figs. 3 and 4). The Upper Triassic sediments examined in this paper consist of a series of facies and facies associations that comprise prodelta, delta front, and delta plain environments, and can best be interpreted in terms of a prograding, fluvial-dominated deltaic system (Coleman and Wright, 1975; Galloway, 1975; Miall, 1984; Elliott, 1986).

\section{Prodelta Facies}

The lower part of the Carnian succession, more than $76 \mathrm{~m}$, is represented by claystones and silty claystones interbedded with clayey siltstones, siltstones, and/or sandy siltstones, together with minor carbonate mudstones (Figs. 3 and 4).

The claystones and silty claystones are generally finely laminated, suggesting oxygen-depleted conditions. They in- clude some burrows, such as Chondrites and halo-type burrows, mollusks, and coccoliths, which indicate an open marine environment (Pl. 1, Fig. 1). Some laminae and burrows are replaced by siderite. Siderite and pyrite concretions are present throughout the claystones and silty claystones (Pl. 1, Fig. 1). Soft-sediment deformation and/or slump structures are typically included in the claystones and siltstones (Pl. 1, Fig. 2).

Interbedded clayey siltstones, siltstones, and sandy siltstones (beds 2 to $43 \mathrm{~cm}$ thick; Figs. 3 and 4 ) are generally normally graded with sharp/flat bases and fine upward into the overlying claystones or silty claystones (Pl. 1, Fig. 1). Parallel laminations and/or ripple cross-laminations are also included in some interbeds.

Finely laminated claystones and silty claystones are typical in a prodelta environment of modern deltas (Coleman and Gagliano, 1965; Allen, 1970; Coleman and Prior, 1980). Marine faunas that indicate an open marine environment also commonly characterize prodelta deposits (Coleman and Prior, 1980). The interbedded clayey siltstones, siltstones, and sandy siltstones may have been deposited out of turbidity currents and/or storm-generated currents (Tankard and Barwis, 1981; Siedlecka et al., 1989), in response to periods of higher flood stage. Prodelta slopes, which experience high depositional rates and large quantities of fine-grained sediments, can be unstable and undergo mass movement of sediments (Coleman and Garrison, 1977; Prior and Suhayda, 1979). The softsediment deformation and/or slump structures in the claystones and silty claystones, therefore, probably represent seafloor failure in a prodelta environment.

The two major coarsening-upward sequences recognized in the Carnian prodelta deposits (Figs. 3 and 4) may indicate progradation of a delta system. 


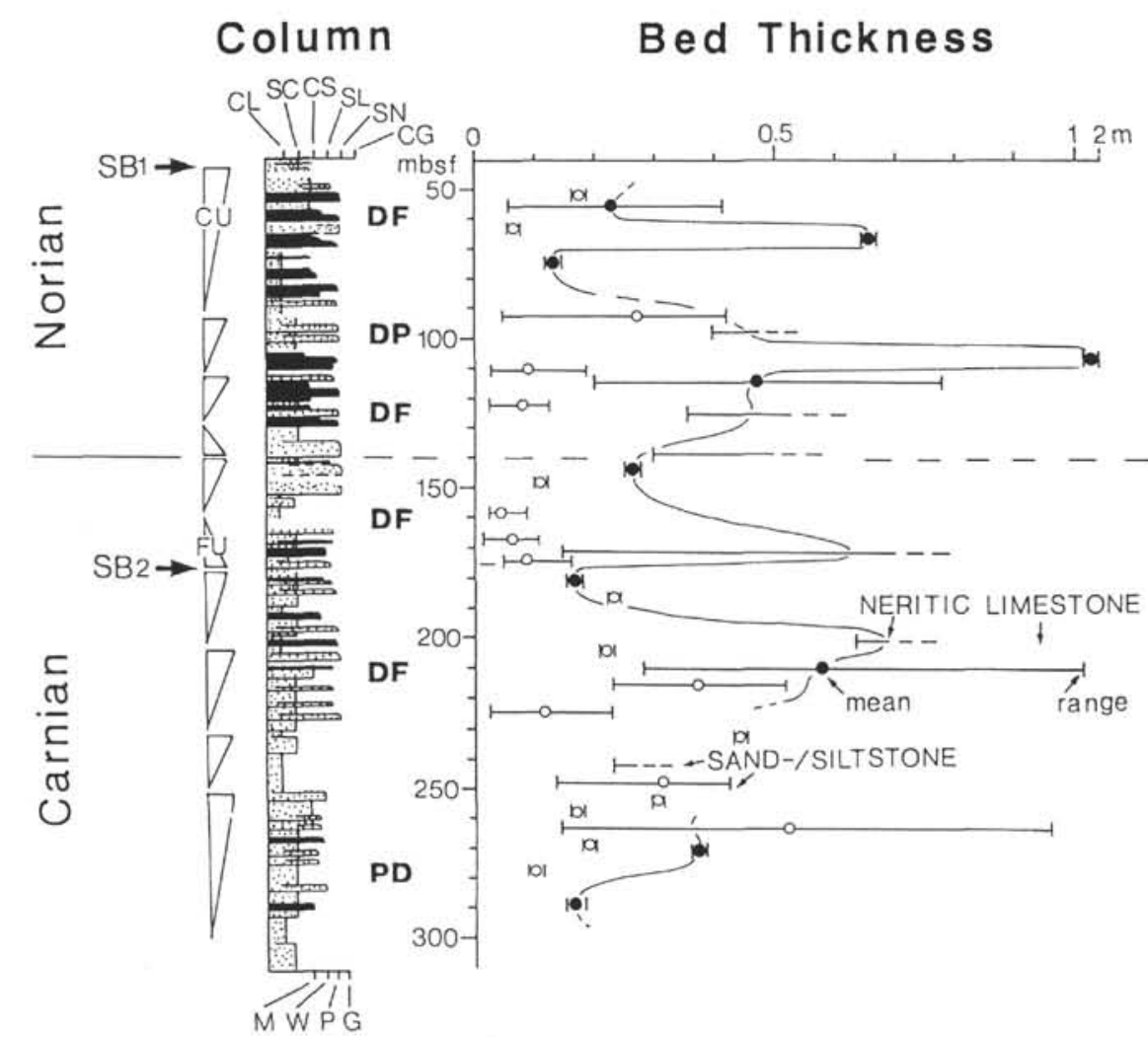

Sandstone Composition $F /(Q t+F)$

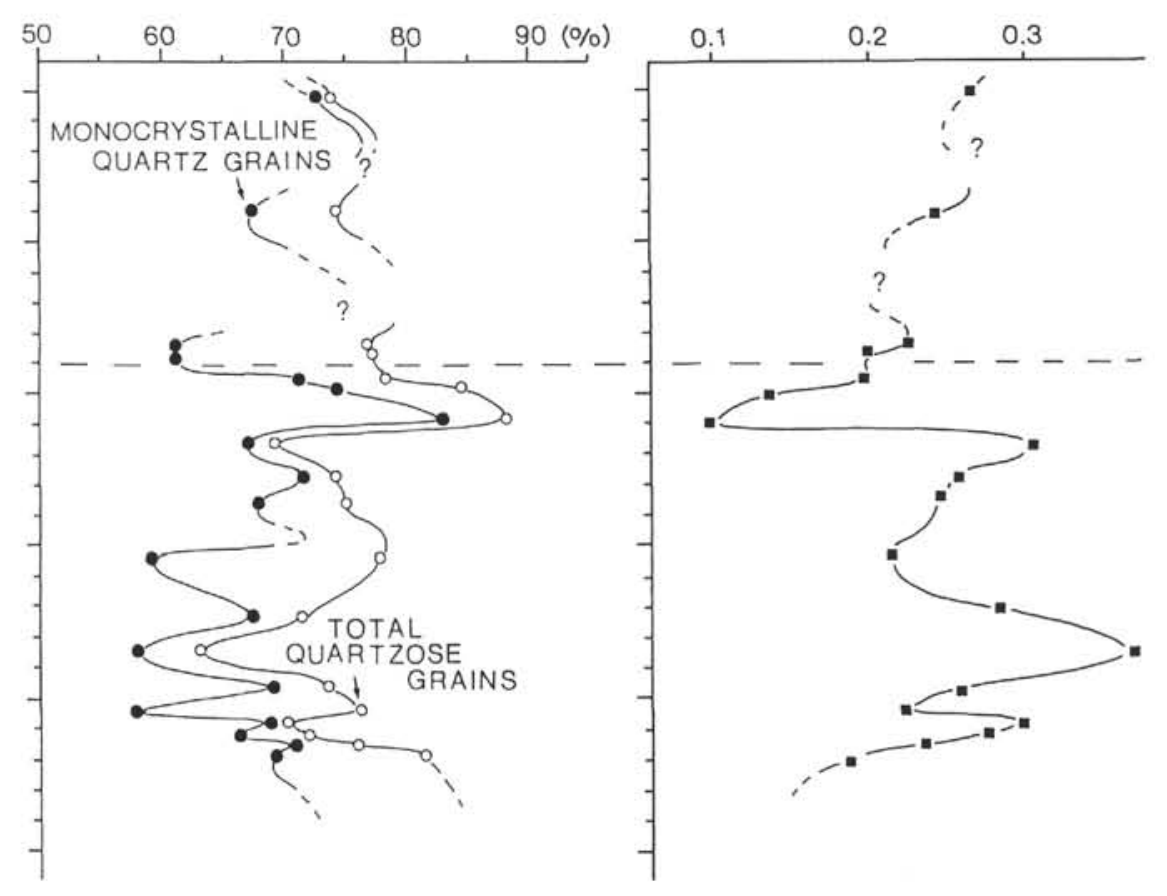

Figure 3. Vertical change in sediment characteristics at Site 759. The columnar section was compiled based on visual core descriptions and logging data. Siliciclastic rocks are stippled and limestones are black. The bed thickness of the sandstone/siltstone and neritic limestone units intercalated in claystones and silty claystones was measured using core photographs. $\mathrm{FU}=$ fining upward, $\mathrm{CU}=$ coarsening upward, $\mathrm{CL}=$ claystone, $\mathrm{SC}=$ silty claystone, $\mathrm{CS}=$ clayey siltstone, $\mathrm{SL}=$ siltstone, $\mathrm{SN}=$ sandstone, $\mathrm{CG}=$ conglomerate, $\mathrm{M}=$ mudstone, $\mathrm{W}=$ wackestone, $\mathrm{P}=$ packstone, $\mathrm{G}=$ grainstone, $\mathrm{DF}=$ delta front, $\mathrm{PD}=$ prodelta, $\mathrm{F}=$ total feldspar grains, and $\mathrm{Qt}=$ total quartzose grains. Sequence stratigraphy from Haq et al. (this volume) and von Rad et al. (this volume). SB1 = sequence boundary at $220 \mathrm{Ma}$ (between Cores 122-759B-6R and 122-759B-7R), SB2 = sequence boundary at $224 \mathrm{Ma}$ (between Cores 122-759B-23R and 122-759B-24R). 


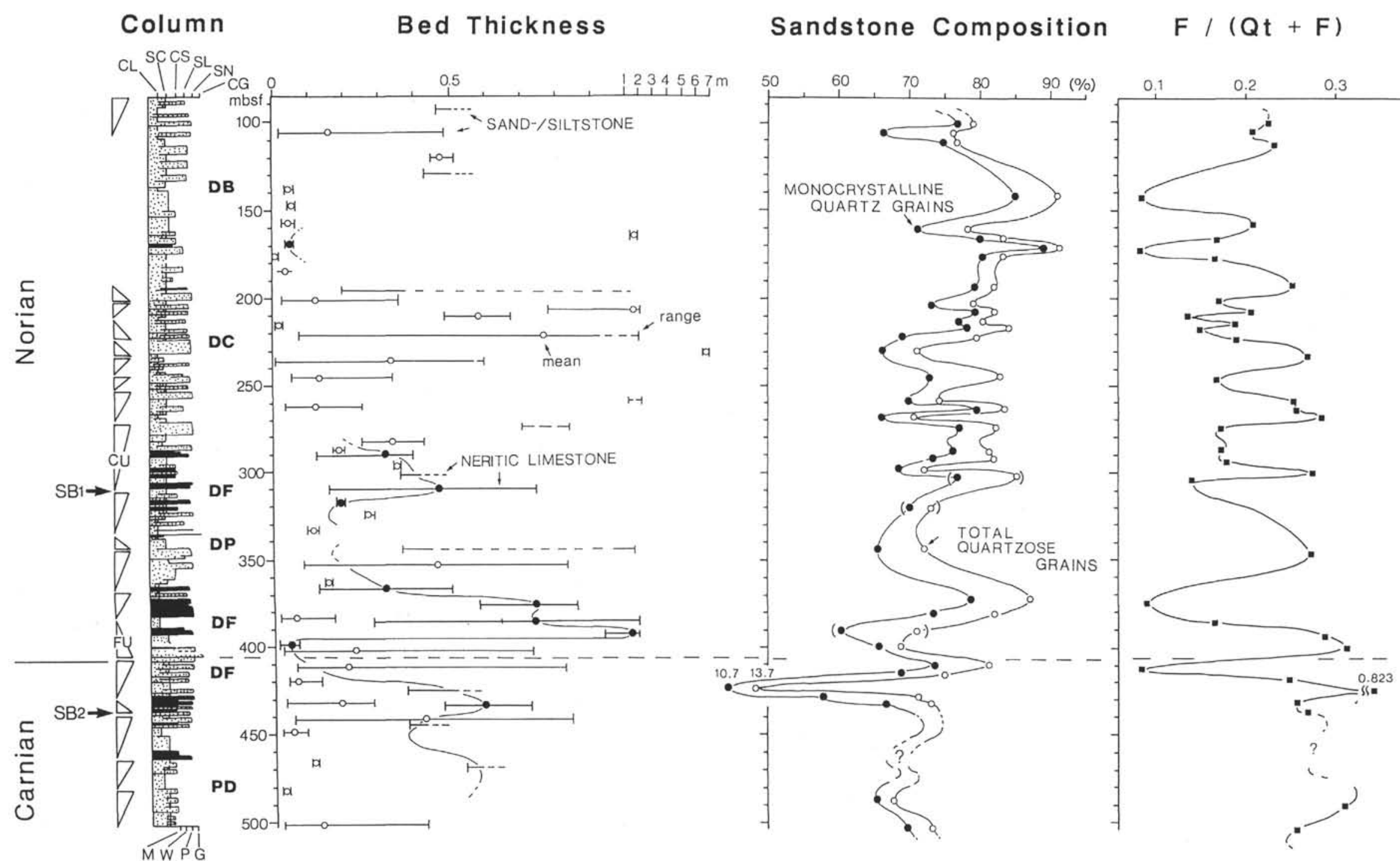

Figure 4. Vertical change in sediment characteristics at Site 760. DC = distributary channel, DB = distributary bay; other abbreviations as in Figure 3. Sandstone composition data in parentheses are from limestones. Sequence stratigraphy from Haq et al. (this volume) and von Rad et al. (this volume). SB1 = sequence boundary at $220 \mathrm{Ma}$ (between Cores $122-760 \mathrm{~B}-8 \mathrm{R}$ and 122-760B-9R), SB2 = sequence boundary at $224 \mathrm{Ma}$ (Section 122-760B-22R-1, $60 \mathrm{~cm}$ ). 


\section{Delta Front Facies}

The middle portion of the Upper Triassic successions is represented by mixed siliciclastic-carbonate cycles (Figs. 3 and 4). Several coarsening-upward sequences 10 to $40 \mathrm{~m}$ thick, from distal bar to distributary mouth bar deposits, are typical in the middle portion.

\section{Distal Bar Facies}

Silty claystones are dominant in the lower part of each coarsening-upward sequence, together with some claystones, and are intercalated with clayey siltstones, siltstones, sandy siltstones, sandstones, and neritic limestones (Figs. 3 and 4). Silty claystones are moderately or partly strongly bioturbated, typically including some Planolites and Chrondrites burrows (Droser and O'Connell, this volume), suggesting more oxygenated depositional conditions. Parallel laminations or ripple cross-laminations and/or flaser bedding are commonly observed in the silty claystones. Soft-sediment deformation structures are also included in the silty claystones. Some siderite and pyrite concretions, about $1-10 \mathrm{~mm}$ in diameter, and siderite layers a few millimeters to a few tens of millimeters thick are commonly included in the silty claystones.

Laminated silty claystones and claystones are the dominant lithology of distal bar deposits in a delta front environment (Coleman and Prior, 1980). Seaward areas of the distal bar are also characterized by high bioturbation (Wright and Coleman, 1974; Coleman and Prior, 1980). Further, parallel laminations and ripple cross-laminations and contorted bedding in silty claystones commonly represent distal bar deposits, which experience more rapid sedimentation and more active wave and current processes than prodelta deposits (Wright and Coleman, 1974; Wright, 1985).

Interbedded clayey siltstones, siltstones, sandy siltstones, and sandstones (beds 2 to $42 \mathrm{~cm}$ thick; Figs. 3 and 4) are normally graded and parallel laminated and/or ripple crosslaminated with sharp/flat or locally erosional basal surfaces (PI. 1, Fig. 3). Lignite seams are commonly intercalated in the upper laminated part of the interbeds. Some sandstone and siltstone interbeds contain shallow-marine molluscan shell fragments in the basal part (Pl. 2, Fig. 1).

The graded and laminated interbeds may indicate a storminduced density-flow origin (Kumar and Sanders, 1976). They are generally coarser than those in prodelta deposits and indicate an increasing proximity to river sources (Baganz et al., 1975).

Interbedded neritic limestones (i.e., grainstone, packstone, wackestone, and carbonate mudstone) are commonly normally graded or parallel laminated with sharp/flat or erosional basal surfaces (PI. 2, Fig. 2). Ripple cross-laminae are also intercalated in the upper part of some limestone interbeds. Graded limestone units commonly begin with grainstone or packstone, or rarely with wackestone, which grades upward into carbonate mudstone. Some neritic limestones rest on carbonate-cemented sandstones or coquina sandstones with transitional basal surfaces. Some carbonate mudstones are also intercalated in silty claystones with sharp/flat or gradational base and top surfaces. The upper part of some of the limestone units is moderately to strongly bioturbated by horizontal burrows. Some limestones, mainly grainstones and packstones and minor wackestones, include detrital grains of quartz, feldspar, and lithic fragments up to 30 volume percent.

Graded limestones, intercalated in the silty claystones of the distal bar deposits, show a common feature of grainy sequences of storm layers (Specht and Brenner, 1979; Aigner, 1982; Kreisa and Bambach, 1982; Handford, 1985). Mixing of siliciclastic and carbonate detritus may have occurred during deposition and/or at the source areas (Mount, 1984). Ripple cross-lamination and bioturbation in the upper part of storm layers may indicate waning current conditions and/or poststorm reworking (Johnson and Baldwin, 1986).

\section{Distributary Mouth Bar Facies}

The upper part of each coarsening-upward sequence is characterized by parallel and/or cross-laminated silty sandstones and sandstones up to about $240 \mathrm{~cm}$ in maximum thickness (Figs. 3 and 4; Pl. 2, Fig. 3). Sandstones are generally fine grained and well sorted. Locally medium-sized grains, bioturbation, and intercalated coal fragments are present. Some dewatering structures were also observed.

The thick sandstone units in the upper part of each coarsening-upward sequence represent distributary mouth bar deposits in a delta front environment (Coleman and Prior, 1980; Wright, 1985). Distinct sedimentary structures and well-sorted grains in the sandstones indicate reworking, not only by stream currents but also by waves in marine water beyond the channel mouth (Coleman and Prior, 1980). Coal fragments may be river-transported organic debris that is present near the top of modern distributary mouth bar deposits (Coleman and Prior, 1980). Dewatering structures may indicate a high sedimentation rate in the distributary mouth bar environment.

\section{Delta Plain Facies}

Minor delta plain deposits overlie the distributary mouth bar deposits of the Norian succession at Sites 759 and 760 . The upper part of the Norian succession at Site 760 is dominated by about $146 \mathrm{~m}$ of delta plain deposits (Fig. 4). At Site 760 , the lowermost $25 \mathrm{~m}$ of the upper part of the Norian succession is represented by distributary channel deposits, and the remainder is distributary bay fill deposits.

\section{Tidal Flat Facies}

Silty claystones or clayey siltstones, 80 to $550 \mathrm{~cm}$ thick, developed on top of some distributary mouth bar deposits of the Norian succession at Sites 759 and 760 , and typically include rootlets and algal mats (Pl. 2, Fig. 4). The silty claystones and clayey siltstones are associated with some limestones with birdseye structures and keystone vugs and shell fragments. Moderate to strong bioturbation structures are also present in some silty claystones.

Algal mats and birdseye structures and keystone vugs in limestones generally characterize intertidal to supertidal flat environments (Tucker, 1981). Bioturbation and rootlets are also commonly observed in tidal flat deposits in the interdistributary regions of modern deltas (Wright, 1985). Primary sedimentary structures may have been obliterated by bioturbation. The tidal flat deposits, which may have developed near distributary mouths, overlie distributary mouth bar deposits in response to seaward progradation of the distributary (Coleman and Prior, 1980).

\section{Distributary Channel Facies}

Three fining-upward sequences are distinct in the distributary channel deposits (Pl. 3, Fig. 1). Each fining-upward sequence begins with parallel and cross-laminated, coarse- to very coarse-grained sandstones that grade upward into parallel and cross-laminated silty fine-grained sandstones or silty sandstones. These, in turn, are overlain by claystones or silty claystones of overbank deposits (Pl. 3, Fig. 1). No distinct bioturbation and marine faunas are included in the distributary channel deposits, which may indicate that fluvial processes prevailed (Wright and Coleman, 1974). Many paleosols, coalified plant fragments, and rootlets were found in the claystones of the upper part of the second fining-upward se- 
quence. Carbonaceous fragments are scattered throughout the deposits and some pyrite concretions, up to $2 \mathrm{~cm}$ in diameter, are also included. Claystones and silty claystones are massive or parallel laminated and are intercalated with parallel laminated siltstones or fine-grained sandstones, 5 to $25 \mathrm{~cm}$ thick. These interbeds may indicate overbank deposits that are generally capped by crevasse splay deposits, as described in the following (Wright, 1985).

\section{Distributary Bay Facies}

Silty claystones and claystones are the dominant lithology in the distributary bay deposits of the upper part of the Norian succession at Site 760 (Fig. 4). They are generally carbonaceous and weakly to moderately bioturbated and are intercalated with siltstones and/or silty fine-grained sandstones from a few centimeters up to $50 \mathrm{~cm}$ thick. The interbeds are generally graded or parallel laminated. Although recovery of the distributary bay deposits of the upper part of the Norian succession at Site 760 is only about $47 \%$, several coarseningupward sequences are identified. Claystones or silty claystones, interbedded with siltstones and/or silty fine-grained sandstones, were deposited at the base with thicker siltstones or fine-grained sandstones above (Fig. 4). The thicker siltstones and fine-grained sandstones of the coarsening-upward sequences are generally structureless. Locally they are crosslaminated and may indicate crevasse splay lobe deposits. The coarsening-upward sequences, which are a well-known characteristic of distributary bay fill sequences in modern delta systems (Coleman and Gagliano, 1964; Coleman and Prior, 1980; Elliott, 1974), are overlain by silty claystones up to $3 \mathrm{~m}$ thick that show fining-upward tendencies. These silty claystones are commonly mottled by rootlets and some include soil profiles, together with scattered carbonate concretions (Pl. 3, Fig. 2). They may represent distributary bay swamp/ marsh deposits (Gagliano and Van Beck, 1970; Coleman and Prior, 1980).

\section{SANDSTONE PETROFACIES}

\section{Methods}

Forty-eight samples were selected from the Carnian to Norian sections at Holes 759B, 760A, and 760B. The average grain size varies among the samples; some samples are very fine- to medium-grained sandstones, whereas others are silty sandstones, sandy siltstones, and siltstones with sands. Therefore, mainly framework grains greater than $0.0625 \mathrm{~mm}$ (very fine-grained sand) were point-counted in the poorly sorted samples. The $10-\mathrm{cm}^{3}$ samples were impregnated and reduced to thin sections. In addition, 10 shipboard thin sections of sandstones and limestones that include siliciclastic detritus of up to $30 \%$ were used to describe petrofacies data in some intervals where no available sandstone samples were collected.

Relative percentages of each framework grain were determined by point-counting 300 grains per thin section. We used the Gazzi-Dickinson point-counting method (Gazzi, 1966; Dickinson, 1970, 1985) to minimize the compositional effects of grain size, which is commonly affected by an environmental variable (Suttner et al., 1981; Ingersoll et al., 1984). Each grain was assigned to one of seven categories (Table 1).

\section{Provenance Type}

The framework composition of the Carnian to Norian sandstones is quite homogeneous. The average ratio of monocrystalline quartz grains $(\mathrm{Qm})$, total feldspar grains $(\mathrm{F})$, and total lithic fragments (Lt) (i.e., the Qm:F:Lt ratio) is $71: 22: 7$. This suggests that the major provenance type is transitional continental, with a minor cratonic interior influence (Dickinson et al., 1983) (Fig. 5).

Monocrystalline quartz grains, showing both undulatory and straight extinction, are the most abundant framework constituent. Some are rounded or well rounded, whereas others are subangular or angular, regardless of the type of extinction (Pl. 4). These monocrystalline quartz grains probably were derived from both acidic plutonic and volcanic rock sources in a continental block. Polycrystalline quartz grains are generally represented by chert fragments and account for $6 \%$ of the average content.

Plagioclase is more common than potassium feldspar (Table 1). Plagioclase is typically twinned and some appears to be replaced by carbonate ( $\mathrm{Pl}$. 4). Microcline is the dominant potassium feldspar, although some orthoclase grains are present.

Lithic fragments are minor framework components and range up to $27.4 \%$, with an average of $7.5 \%$ (Table 1). Sedimentary rock fragments are generally less than $3.7 \%$ and are mainly siltstones and silty claystones. Volcanic rock fragments are also minor constituents, but are $23.7 \%$ in Sample 122-760B-20R-4, 24-26 cm, $14.3 \mathrm{~m}$ below the Carnian/ Norian boundary (Table 1). They are characterized by a trachytic texture and include many plagioclase grains (PI. 4, Fig. 4). Above the Carnian/Norian boundary, some sandstone samples continue to include minor volcanic rock fragments with a trachytic texture. This suggests the onset of riftingrelated volcanism since the latest Carnian (Exon et al., 1982). Metasedimentary lithic fragments are also minor framework components at less than $0.7 \%$. They are foliated quartzose rocks with minor phyllosilicate. The most likely source for these low-grade metamorphic lithic fragments is the locally metamorphosed, fine-grained sedimentary rocks, such as those in the Pilbara Precambrian block.

Mica grains are the most abundant accessory minerals and constitute up to $11 \%$ of the framework composition. Zircon and glauconite grains are also distinct accessory minerals but are generally less than $1 \%$. Therefore, accessory minerals were generally ignored in the petrofacies analysis.

\section{Vertical Change}

The generally homogeneous framework composition of the Carnian and Norian sandstones shows distinct vertical changes in the relative ratio of monocrystalline quartz grains and total quartzose grains (Figs. 3 and 4). Vertical changes are also observed in the fluctuation of the relative content of total feldspar grains (Figs. 3 and 4).

The relative ratio of monocrystalline quartz grains and total quartzose grains, hereafter called quartz content, generally decreases until the end of the Carnian succession. Quartz content increases toward the upper portion of the Norian succession, and then decreases at the uppermost portion of the Norian succession again (Figs. 3 and 4 and Table 1).

Overall changes in the quartz content include minor fluctuations that correspond to coarsening-upward sequences in the prodelta, delta front, and delta plain deposits. Sandstoneprone deposits were generally introduced by fluvial-dominated processes, such as the progradation of mouth bars in a delta front environment and crevasse splay lobes in a delta plain environment. Sandstones with higher quartz contents tend to be deposited in the lower part of each coarseningupward sequence, where they are typically intercalated with neritic limestones (Figs. 3 and 4).

The changes in the quartz content may have been affected by temporal fluctuations in the relative volume of source rock types in the provenance terranes. The general decrease in the quartz content indicates an increased contribution of feld- 
Table 1. Framework composition of Carnian to Norian sandstones from the Wombat Plateau, normalized to $100 \%$.

\begin{tabular}{|c|c|c|c|c|c|c|c|c|c|c|c|}
\hline \multirow[b]{2}{*}{ Age } & \multirow[b]{2}{*}{$\begin{array}{l}\text { Core, section, } \\
\text { interval }(\mathrm{cm})\end{array}$} & \multicolumn{2}{|c|}{ Quartz grains } & \multicolumn{2}{|c|}{ Feldspar grains } & \multicolumn{3}{|c|}{ Lithic fragments } & \multirow{2}{*}{$\begin{array}{c}\text { Total } \\
\text { quartzose } \\
\text { grainsa }\end{array}$} & \multirow{2}{*}{$\begin{array}{c}\text { Total } \\
\text { lithic } \\
\text { fragments }\end{array}$} & \multirow{2}{*}{$\begin{array}{c}\text { Total } \\
\text { feldspar } \\
\text { grainse }\end{array}$} \\
\hline & & $\begin{array}{l}\text { Mono- } \\
\text { crystalline }\end{array}$ & $\begin{array}{c}\text { Poly- } \\
\text { crystalline }\end{array}$ & $\begin{array}{c}\text { Plagio- } \\
\text { clase }\end{array}$ & Potassium & $\begin{array}{c}\text { Sedi- } \\
\text { mentary }\end{array}$ & Volcanic & $\begin{array}{c}\text { Meta- } \\
\text { morphic }\end{array}$ & & & \\
\hline \multirow[t]{39}{*}{ Norian } & $122-759 \mathrm{~B}-$ & & & & & & & & & & \\
\hline & $7 \mathrm{R}-1,19-23$ & 73.0 & 0.5 & 24.0 & 2.6 & 0 & 0 & 0 & 73.5 & 0.5 & 26.6 \\
\hline & $11 \mathrm{R}-2,12-14$ & 67.2 & 7.2 & 15.8 & 7.9 & 2.0 & 0 & 0 & 74.4 & 9.2 & 23.7 \\
\hline & $16 \mathrm{R}-1,40-43$ & 61.6 & 15.3 & 16.0 & 6.0 & 0.7 & 0.3 & 0 & 76.9 & 16.3 & 22.0 \\
\hline & $16 \mathrm{R}-1,80-82$ & 61.7 & 15.3 & 11.3 & 8.0 & 3.7 & 0 & 0 & 77.0 & 19.0 & 19.3 \\
\hline & $122-760 \mathrm{~A}-$ & & & & & & & & & & \\
\hline & $12 X-2,8-10$ & 77.0 & 2.0 & 17.0 & 3.7 & 0.3 & 0 & 0 & 79.0 & 2.3 & 20.7 \\
\hline & $16 \mathrm{X}-5,118-120$ & 85.0 & 6.0 & 5.3 & 3.0 & 0.7 & 0 & 0 & 91.0 & 6.7 & 8.3 \\
\hline & $18 \mathrm{X}-\mathrm{CC}, 13-16$ & 71.0 & 7.7 & 12.3 & 8.7 & 0.3 & 0 & 0 & 78.7 & 8.0 & 21.0 \\
\hline & $19 \mathrm{X}-1,82-84$ & 80.3 & 2.7 & 12.7 & 4.3 & 0 & 0 & 0 & 83.0 & 2.7 & 17.0 \\
\hline & $19 \times-4,27-29$ & 89.7 & 1.7 & 7.7 & 1.0 & 0 & 0 & 0 & 91.4 & 1.7 & 8.7 \\
\hline & $20 \mathrm{X}-2,96-98$ & 80.7 & 2.4 & 13.9 & 2.7 & 0.3 & 0 & 0 & 83.1 & 2.7 & 16.6 \\
\hline & $22 X-3,56-58$ & 71.0 & 3.0 & 19.0 & 6.3 & 0.3 & 0.3 & 0 & 74.0 & 3.6 & 25.3 \\
\hline & $23 \mathrm{X}-\mathrm{CC}, 29-31$ & 79.3 & 3.3 & 15.0 & 2.0 & 0.3 & 0 & 0 & 82.6 & 3.6 & 17.0 \\
\hline & $24 \mathrm{X}-\mathrm{CC}, 25-27$ & 79.7 & 2.7 & 13.3 & 3.7 & 0.3 & 0.3 & 0 & 82.4 & 3.3 & 17.0 \\
\hline & $25 \mathrm{X}-1,96-98$ & 73.3 & 5.7 & 19.3 & 1.3 & 0.3 & 0 & 0 & 79.0 & 6.0 & 20.6 \\
\hline & $25 X-2,39-41$ & 83.3 & 2.3 & 10.3 & 4.0 & 0 & 0 & 0 & 85.6 & 2.3 & 14.3 \\
\hline & $26 X-1,61-64$ & 77.0 & 3.7 & 15.7 & 3.7 & 0 & 0 & 0 & 80.7 & 3.7 & 19.4 \\
\hline & $26 \mathrm{X}-2,112-115$ & 78.0 & 6.7 & 9.7 & 5.3 & 0.3 & 0 & 0 & 84.7 & 7.0 & 15.0 \\
\hline & 28X-CC, $41-44$ & 69.3 & 9.7 & 13.0 & 5.0 & 2.7 & 0.3 & 0 & 79.0 & 12.7 & 18.0 \\
\hline & $29 \mathrm{X}-4,118-120$ & 66.0 & 5.3 & 18.0 & 8.7 & 1.3 & 0.3 & 0.3 & 71.3 & 7.2 & 26.7 \\
\hline & $31 X-3,129-131$ & 73.3 & 9.7 & 11.0 & 5.0 & 1.0 & 0 & 0 & 83.0 & 10.7 & 16.0 \\
\hline & $33 \mathrm{X}-\mathrm{CC}, 7-10$ & 70.3 & 4.0 & 20.0 & 5.3 & 0.3 & 0 & 0 & 74.3 & 4.3 & 25.3 \\
\hline & $34 \mathrm{X}-\mathrm{CC}, 14-16$ & 79.3 & 4.3 & 12.7 & 3.0 & 0.3 & 0 & 0 & 83.6 & 4.9 & 25.7 \\
\hline & $35 X-6,17-19$ & 66.0 & 4.3 & 23.3 & 4.7 & 0 & 1.0 & 0.7 & 70.3 & 6.0 & 28.0 \\
\hline & $36 \mathrm{X}-1,38-40$ & 77.7 & 4.7 & 12.3 & 4.7 & 0.7 & 0 & 0 & 82.4 & 5.4 & 17.0 \\
\hline & $122-760 \mathrm{~B}-$ & & & & & & & & & & \\
\hline & 3R-CC, 8-11 & 66.0 & 10.3 & 19.0 & 3.0 & 1.0 & 0.3 & 0.3 & 76.3 & 11.9 & 22.0 \\
\hline & $4 R-1,2-5$ & 75.1 & 1.5 & 19.5 & 4.0 & 0 & 0 & 0 & 76.6 & 1.5 & 23.5 \\
\hline & $6 \mathrm{R}-2,23-26$ & 73.7 & 8.3 & 14.0 & 4.0 & 0 & 0 & 0 & 82.0 & 8.3 & 18.0 \\
\hline & $6 \mathrm{R}-2,39-42$ & 76.3 & 5.0 & 14.3 & 3.0 & 1.0 & 0.3 & 0 & 81.3 & 6.3 & 17.3 \\
\hline & $7 \mathrm{R}-1,12-15$ & 68.2 & 4.5 & 22.6 & 4.8 & 0 & 0 & 0 & 72.7 & 4.5 & 27.4 \\
\hline & 7R-CC, $40-42$ & 77.0 & 8.0 & 12.0 & 2.0 & 0 & 1.0 & 0 & 85.0 & 9.0 & 14.0 \\
\hline & $9 R-2,38-42$ & 70.0 & 3.0 & 19.0 & 2.0 & 0 & 0 & 0 & 73.0 & 9.0 & 21.0 \\
\hline & $12 \mathrm{R}-1,136-139$ & 65.8 & 6.0 & 23.3 & 4.5 & 0.4 & 0 & 0 & 71.8 & 6.4 & 27.8 \\
\hline & $16 \mathrm{R}-2,21-24$ & 79.3 & 8.0 & 6.7 & 2.3 & 1.0 & 2.0 & 0.7 & 87.3 & 11.7 & 9.0 \\
\hline & $17 \mathrm{R}-1,1-3$ & 73.7 & 9.0 & 12.3 & 4.3 & 0.3 & 0.3 & 0 & 82.7 & 9.6 & 16.6 \\
\hline & $17 \mathrm{R}-2,15-18$ & 60.0 & 11.0 & 26.0 & 3.0 & 0 & 0 & 0 & 71.0 & 11.0 & 29.0 \\
\hline & $18 \mathrm{R}-2,49-51$ & 65.6 & 3.2 & 27.2 & 3.9 & 0 & 0 & 0 & 68.8 & 3.2 & 31.1 \\
\hline \multirow[t]{24}{*}{ Carnian } & $122-759 \mathrm{~B}-$ & & & & & & & & & & \\
\hline & $17 \mathrm{R}-1,10-12$ & 71.3 & 7.0 & 11.0 & 8.0 & 0.7 & 2.0 & 0 & 78.3 & 9.7 & 19.0 \\
\hline & $17 \mathrm{R}-1,23-25$ & 74.6 & 10.0 & 8.4 & 4.3 & 2.3 & 0.3 & 0 & 84.6 & 12.6 & 12.7 \\
\hline & $18 \mathrm{R}-1,5-12$ & 83.0 & 5.0 & 5.7 & 4.0 & 1.7 & 0.3 & 0.3 & 88.0 & 7.3 & 9.7 \\
\hline & 19R-2, 112-115 & 67.0 & 2.0 & 27.9 & 3.0 & 0 & 0 & 0 & 69.0 & 2.0 & 30.9 \\
\hline & $20 \mathrm{R}-3,113-116$ & 71.8 & 2.7 & 23.8 & 1.7 & 0 & 0 & 0 & 74.5 & 2.7 & 25.5 \\
\hline & $21 \mathrm{R}-2,24-26$ & 68.0 & 7.3 & 16.0 & 8.0 & 0.7 & 0 & 0 & 75.3 & 8.0 & 24.0 \\
\hline & $23 R-3,1-4$ & 59.3 & 18.3 & 15.7 & 5.3 & 1.0 & 0.3 & 0 & 77.6 & 19.6 & 21.0 \\
\hline & $24 \mathrm{R}-2,115-117$ & 67.7 & 3.7 & 22.0 & 6.7 & 0 & 0 & 0 & 71.4 & 3.7 & 28.7 \\
\hline & $26 \mathrm{R}-1,27-30$ & 57.5 & 5.7 & 33.0 & 3.7 & 0 & 0 & 0 & 63.2 & 5.7 & 36.7 \\
\hline & $29 \mathrm{R}-1,51-53$ & 69.7 & 4.0 & 21.3 & 4.3 & 0.7 & 0 & 0 & 73.7 & 4.7 & 25.6 \\
\hline & $30 \mathrm{R}-1,4-7$ & 57.3 & 18.7 & 16.7 & 4.7 & 2.3 & 0.3 & 0 & 76.0 & 21.6 & 21.4 \\
\hline & $31 \mathrm{R}-2,25-28$ & 69.0 & 1.0 & 28.0 & 2.0 & 0 & 0 & 0 & 70.0 & 1.0 & 30.0 \\
\hline & $32 \mathrm{R}-1,83-84$ & 66.7 & 5.3 & 22.3 & 5.0 & 0.7 & 0 & 0 & 72.0 & 6.0 & 27.3 \\
\hline & $32 \mathrm{R}-1,115-118$ & 71.3 & 4.7 & 17.3 & 6.0 & 0.7 & 0 & 0 & 76.0 & 5.4 & 23.3 \\
\hline & $33 \mathrm{R}-1,72-74$ & 69.7 & 11.7 & 14.3 & 4.0 & 0.3 & 0 & 0 & 81.4 & 12.0 & 18.3 \\
\hline & $122-760 \mathrm{~B}-$ & & & & & & & & & & \\
\hline & $19 \mathrm{R}-1,78-80$ & 74.0 & 7.7 & 14.7 & 3.3 & 0.3 & 0 & 0 & 81.7 & 8.0 & 18.0 \\
\hline & $20 \mathrm{R}-3,71-74$ & 69.0 & 6.3 & 19.0 & 5.3 & 0 & 0.3 & 0 & 75.3 & 6.6 & 24.3 \\
\hline & $20 \mathrm{R}-4,24-26$ & 10.7 & 2.7 & 61.3 & 0.7 & 1.0 & 23.7 & 0 & 13.4 & 27.4 & 62.0 \\
\hline & $21 \mathrm{R}-3,62-64$ & 58.0 & 14.3 & 23.3 & 2.0 & 0.7 & 1.7 & 0 & 72.3 & 16.7 & 25.3 \\
\hline & $21 \mathrm{R}-3,71-75$ & 67.7 & 5.3 & 19.7 & 7.3 & 0 & 0 & 0 & 73.0 & 5.3 & 27.0 \\
\hline & $27 \mathrm{R}-6,28-30$ & 65.7 & 2.1 & 28.3 & 3.1 & 0 & 0.3 & 0 & 67.8 & 2.4 & 31.8 \\
\hline & $29 \mathrm{R}-4,93-95$ & 70.0 & 3.0 & 23.7 & 3.0 & 0 & 0.3 & 0 & 73.0 & 3.3 & 26.7 \\
\hline
\end{tabular}

\footnotetext{
${ }^{\text {a }}$ Monocryatalline + polycrystalline quartz grains.

b Sedimentary + volcanic + metamorphic lithic fragments.

${ }^{c}$ Plagioclase + potassium feldspar grains.
} 

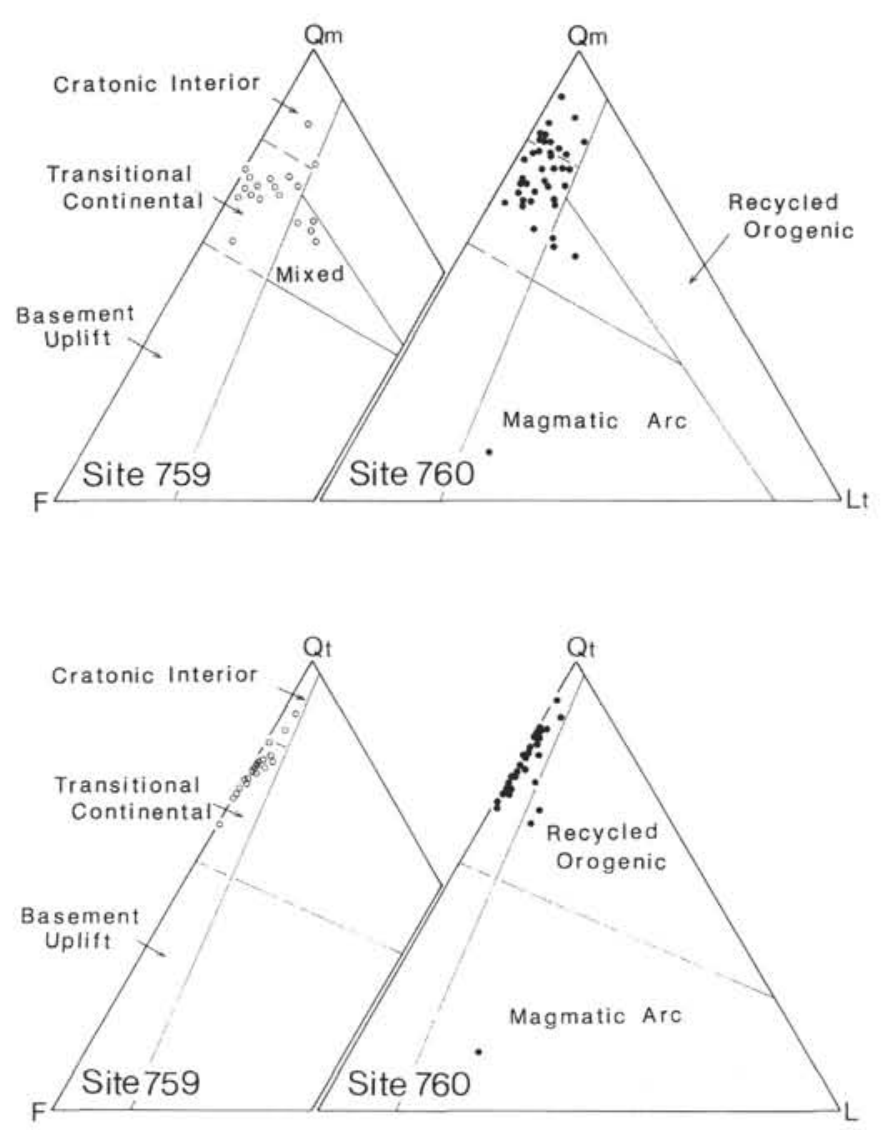

Figure 5. Framework composition of the Upper Triassic sandstones from the Wombat Plateau. Provenance fields are from Dickinson et al. (1983). Qm = monocrystalline quartz grains, $\mathrm{F}=$ total feldspar grains, $\mathrm{Lt}=$ total lithic fragments, $\mathrm{Qt}=$ total quartzose grains, and $\mathrm{L}=$ total unstable lithic fragments.

spathic detritus from the provenance terranes. The increase of feldspathic detritus generally corresponds to incipient rifting and/or basement uplift along fault zones within a continental block (Dickinson, 1985). The tectonic movement may have been accompanied by trachytic volcanism since the latest Carnian. Tectonic fluctuations appear to have occurred at the Carnian/Norian boundary and during the latest Norian. On the other hand, the increase in the quartz content during the Norian may indicate wearing down of the quartzose basement rocks and/or erosion of the uplifted incipient rift shoulder. Alternatively, appreciable weathering during temporary storage on a flood plain under tropical to subtropical climatic conditions also appears to have introduced the more quartzose sandstones (Suttner et al., 1981; Dickinson, 1985).

The higher quartz content in the lower part of each coarsening-upward deltaic sequence suggests that more active marine processes, such as abrasion and destruction of siliciclastic detritus by waves and currents, prevailed. Reworking of the underlying deltaic sediments may also have occurred in response to transgressions, forming the compositionally more mature, quartzose sediments in the lower part of each sequence. The minor fluctuations in the quartz content, therefore, appear to have been affected by different dynamic conditions in response to the transgression-regression cycles of a fluviodeltaic system. Alternatively, even minor fluctuations appear to have been affected by ephemeral changes in geological composition in the provenance terranes. The sec- ond interpretation suggests that the development of each coarsening-upward sequence was also controlled by riftingrelated tectonic movement.

\section{DEPOSITIONAL CYCLES}

The Carnian to Norian successions at the Wombat Plateau show distinct depositional cycles, characterized by cyclic changes of depositional facies and sandstone petrofacies, together with the carbonate petrofacies that are described in detail in the carbonate petrology papers in this volume (Borella et al., this volume; Dumont, this volume; Röhl et al., this volume; Sarti et al., this volume). The depositional cycles are also characterized by vertical change in the apparent dips and total organic carbon content (TOC) (Figs. 6 and 7). Cyclic sedimentation revealed by the wireline geophysical logs in the Triassic section at Site 759 is discussed elsewhere (Golovchenko et al., this volume; Boyd and Bent, this volume).

Apparent dips of the Carnian to Norian sediments were measured on the core photographs, assuming that the hole was vertical and that the parallel laminae and/or bedding were initially horizontal. Measurements were not made on highly disturbed or biscuited core sections. Foresets of cross-laminae were also excluded from the measurements.

Even allowing for minor fluctuations, the apparent dips largely decrease upward. At Hole $760 \mathrm{~B}$ they show a distinct change at the Carnian/Norian boundary (Figs. 6 and 7). Minor fluctuations in the apparent dips largely correspond to the coarsening-upward sequences of a prograding delta system (Figs. 6 and 7). Sandstone-/siltstone-prone intervals are generally characterized by higher apparent dips. We interpret this to indicate a higher initial dip of the sediments in response to progradation of delta lobe clinoforms. The higher apparent dips are also distinct in the distributary channel deposits in the middle part of the Norian succession at Site 760 (Fig. 7). On the other hand, these higher apparent dips may be a result of lateral accretion in fluvial sediments that apparently look like highly inclined parallel lamination in cores.

Organic carbon in the Carnian and Norian sediments is dominated by type III (higher land-plant debris), on the basis of the low hydrogen index values (Haq, von Rad, O'Connell, et al., 1990). Therefore, the vertical fluctuations in TOC, represented by higher values in the sandstone-/siltstone-prone intervals (Figs. 6 and 7), also correspond to the progradation of a fluviodeltaic system that deposited land plants in marginal marine environments (Coleman and Prior, 1980).

The basal portion of each coarsening-upward sequence in these delta systems ( 5 to $30 \mathrm{~m}$ thick) is generally defined by an abrupt lithologic change from the sandstone-/siltstoneprone mouth bar or tidal flat deposits with algal mats and rootlets to mudstone-prone delta front deposits. In the basal portion of the mudstone-prone delta front sediments, shelly sandstone-/siltstone-prone interbeds and minor conglomerates of storm origin were typically deposited (PI. 5), probably in response to transgressions. Some basal deposits above the Carnian/Norian boundary are represented by thicker sandstones with parallel and/or ripple cross-laminations and show fining-upward sequences. The sandstones contain shell fragments and minor glauconite grains and are moderately to locally highly bioturbated. These basal sandstones may indicate reworking of earlier deltaic deposits by marine processes in response to transgressions (Miall, 1984). Therefore, the boundary between the basal deposits and the underlying distributary mouth bar/tidal flat deposits may represent marine flooding surfaces (Van Wagoner et al., 1988). Within or above these basal deposits, neritic limestones are typically intercalated in the delta front deposits, 


\section{Column Apparent Dip TOC}

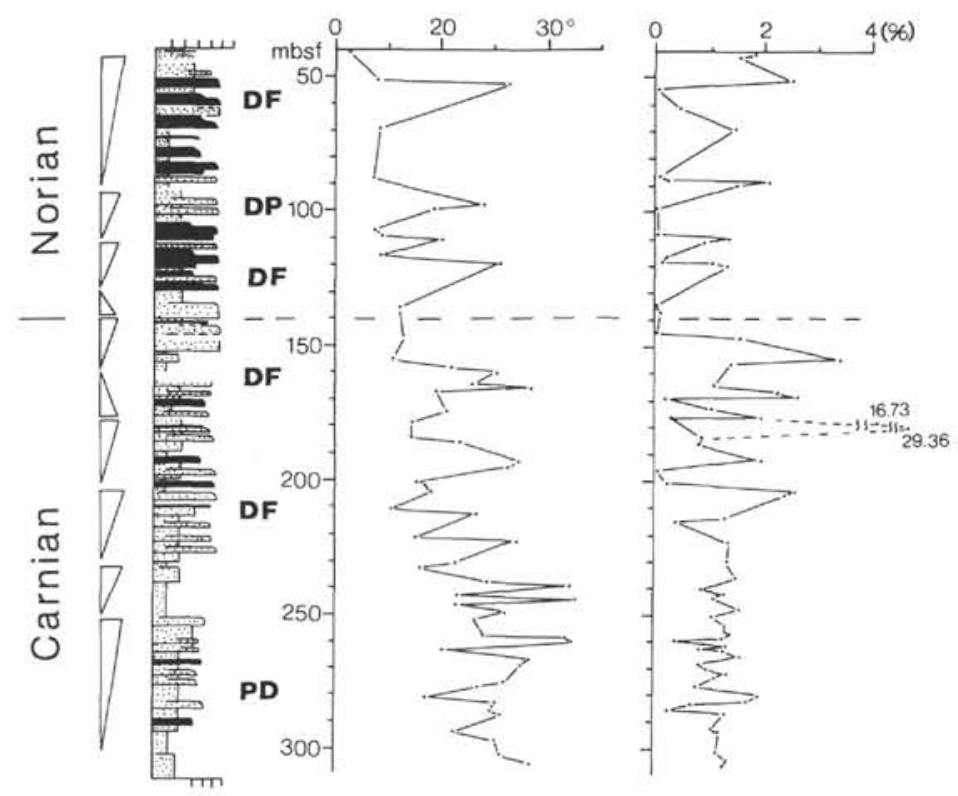

Figure 6. Vertical change of apparent dips of the sediments measured using core photographs and total organic carbon content at Site 759, adopted from Haq, von Rad, O'Connell, et al. (1990). See Figure 3 for abbreviations.

together with minor sandstone-/siltstone-prone interbeds (Figs. 4 and 5). Especially above the Carnian/Norian boundary, the bed thickness of neritic limestones abruptly increases in the delta front deposits (Figs. 3 and 4). Therefore, the mixed siliciclastic and carbonate rocks in the Carnian to Norian successions were developed in response to transgressions that superimposed a new prograding deltaic system onto the older ones.

Compaction and/or subsidence allow a local marine transgression to occur in response to an abandonment phase of delta lobes (Miall, 1984). Based on a sequence stratigraphic analysis of the Carnian and Norian successions at Sites 759 and 760 (Haq et al., this volume; von Rad et al., this volume), each coarsening-upward deltaic cycle at Sites 759 and 760 can largely be correlated (Figs. 3 and 4). Each transgressionregression cycle in the deltaic deposits at Sites 759 and 760 may be nearly time equivalent. Further, the thickest carbonate rocks were deposited following the maximum marine flooding stage at the Carnian/Norian boundary (Haq et al., this volume; von Rad et al., this volume) (Figs. 3 and 4). Therefore, a long-term overprint of relative sea-level change may also have been present, and have influenced the development of the mixed siliciclastic and carbonate deltaic cycles.

A fluctuating supply of siliciclastic detritus is generally unfavorable for actively developing shoals, reefs, and/or banks. Because the turbidity would have blocked sunlight and the high deposition rates smothered the growing carbonates, allochemical components of the Carnian and Norian carbonate rocks are likely to have been supplied by storm-related waves and currents. The fluctuating supply of terrigenous sediments was controlled mainly by the migration of delta lobes. We therefore interpret the development of the mixed siliciclastic/carbonate cycles in the Carnian to Norian deltaic successions to have been controlled by marine transgression overprinted by deltaic sedimentation, such as the migration of delta lobes (Fig. 8). Mixed cyclic siliciclastic and carbonate rocks have been interpreted in terms of transgression-regres- sion cycles at other marginal marine settings (Moore, 1964; Matthews, 1974; Driese and Dott, 1984; Mack and James, 1985; Blair, 1988).

\section{CONCLUSIONS}

The Carnian to Norian successions recovered from Sites 759 and 760 on the Wombat Plateau are represented by fluviodeltaic deposits. Depositional facies and facies associations indicate that the Late Triassic deltaic system is classified as a fluvial-dominated delta type. Modern examples are the Mississippi, Po, and Danube river deltas (Galloway, 1975). The fluvial-dominated deltaic deposits on the Wombat Plateau are also characterized by mixed siliciclastic and carbonate cycles.

The development of mixed siliciclastic and carbonate cycles in the Carnian to Norian successions was controlled mainly by marine transgressions and the following progradation of delta lobes. Except for the Carnian prodelta and delta front deposits, which typically contain open marine nannofossil floras (Haq, von Rad, O'Connell, et al., 1990), most of the Norian mudstone-prone delta front sediments are interpreted to be restricted marine deposits, based on palynology (Haq, von Rad, O'Connell, et al., 1990; Brenner, this volume, chapter 23). The development of a restricted marine environment, such as a large lagoonal environment, may have been accompanied by the two major transgressions during the late Carnian and middle Norian (i.e., sequence boundaries at 220 and $224 \mathrm{Ma}$; Haq et al., this volume; von Rad et al., this volume). During these transgressions a large lagoonlike restricted marine environment developed at the area of Sites 759 and 760 during the late Carnian through the Norian.

The general sedimentological setting for the late Carnian to Norian deltaic successions on the Wombat Plateau appears to have been equivalent to the present Gulf Coast area (cf. Coleman and Gagliano, 1964; Penland and Boyd, 1981; Penland et al., 1986). Around the seaward barriers and/or delta lobes, carbonate banks or shoals may have developed. These carbonates may have provided allochemical components of the neritic limestones 


\section{Column}

Apparent Dip

TOC

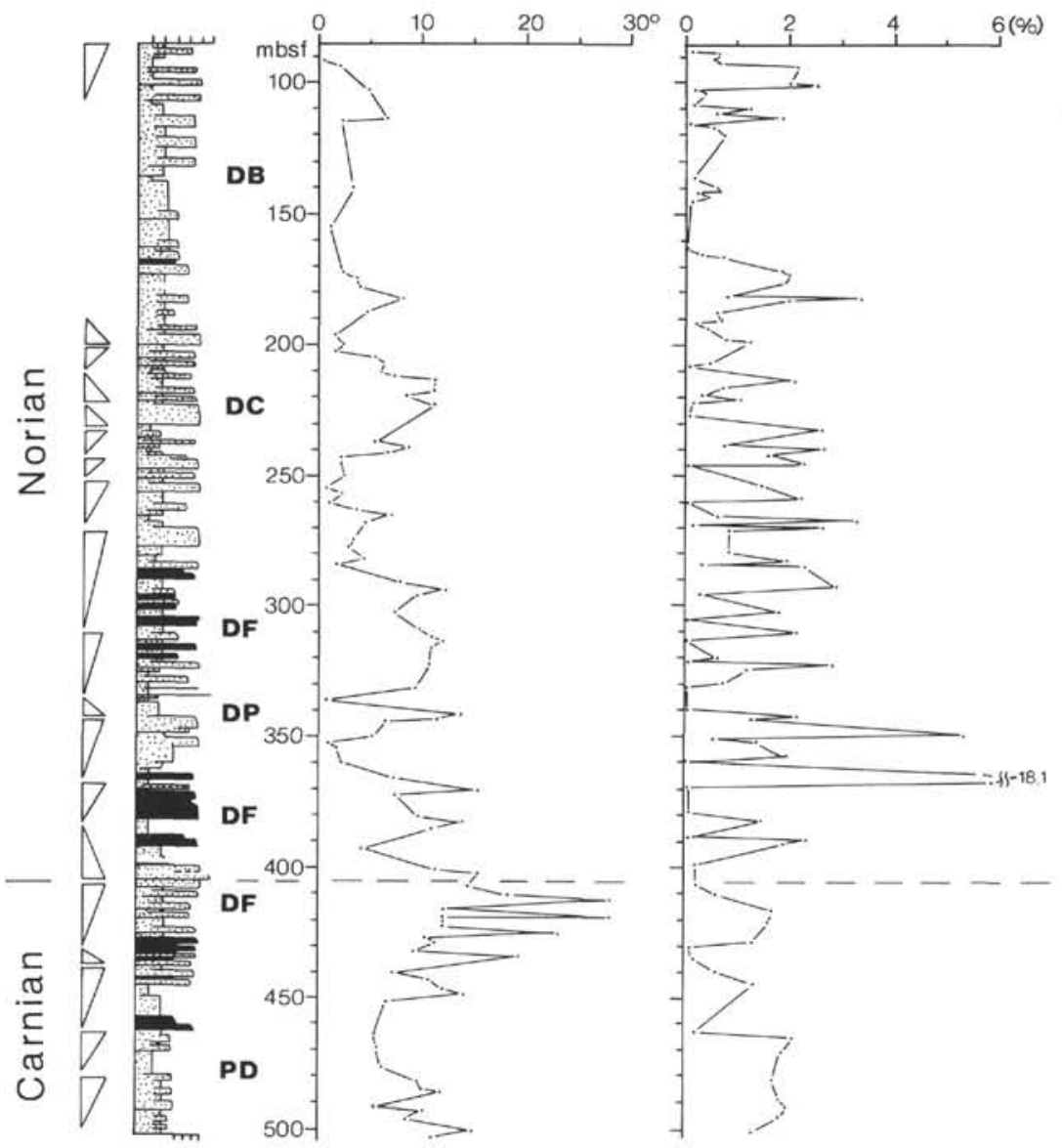

Figure 7. Vertical change of apparent dips of the sediments and total organic carbon content at Site 760 . See Figure 3 for abbreviations.

to the prodelta and delta front environments by overwash processes and/or storm waves. Some carbonate rocks include up to $30 \%$ siliciclastic detritus, and the mixed lithology may have formed during transportation. Alternatively the mixed lithology may have been initiated at the base of carbonate shoals/banks, where broken shell fragments and siliciclastics from the barriers or delta lobes were deposited before transportation into prodelta, delta front, and/or lagoon environments. To confirm this depositional model, we need more detailed information about the sedimentological characteristics at additional offshore sites, between Sites 760 and 761 and in deeper portions of the sediments at Sites 761 and 764 . Unfortunately this sedimentary material is not available for study.

\section{ACKNOWLEDGMENTS}

We would like to thank the Ocean Drilling Program for allowing our participation on Leg 122 and supporting our post-cruise studies. We thank J. M. Coleman, A. Taira, and U. von Rad for their critical comments, which greatly helped to improve the manuscript.

\section{REFERENCES}

Aigner, T., 1982. Calcareous tempesties: storm-dominated stratification in Upper Muschelkalk limestones (Middle Trias, SW-Germany). In Einsele, G., and Seilacher, A. (Eds.), Cyclic and Event Stratification: Berlin (Springer-Verlag), 180-198.
Allen, J.R.L., 1970. Sediments in the modern Niger Delta. In Morgan, J. P. (Ed.), Deltaic Sedimentation. Spec. Publ.-Soc. Econ. Paleontol. Mineral., 15:138-151.

Baganz, B. P., Horne, J. C., and Ferm, J. C., 1975. Carboniferous and recent Mississippi lower delta plains: a comparison. Trans. Gulf Coast Assoc. Geol. Soc., 25:183-191.

Blair, T. N., 1988. Mixed siliciclastic-carbonate marine and continental syn-rift sedimentation, Upper Jurassic-lowermost Cretaceous Todos Santos and San Ricardo formations, Western Chiapas, Mexico. J. Sediment. Petrol., 58:623-636.

Coleman, J. M., and Gagliano, S. M., 1964. Cyclic sedimentation in the Mississippi River deltaic plain. Trans. Gulf Coast Assoc. Geol. Soc., 14:67-80.

1965. Sedimentary structures: Mississippi River deltaic plain. In Middleton, G. V. (Ed.), Primary Sedimentary Structures and Their Hydrodynamic Interpretation. Spec. Publ.-Soc. Econ. Paleontol. Mineral., 12:133-148.

Coleman, J. M., and Garrison, L. E., 1977. Geological aspects of marine slope instability, northwestern Gulf of Mexico. Mar. Geotech., 2:9-44.

Coleman, J. M., and Prior, D. B., 1980. Deltaic Sand Bodies. Short Course Education Course Note Ser., AAPG, 5.

Coleman, J. M., and Wright, L. D., 1975. Modern river deltas: variability of processes and sand bodies. In Broussard, M. L. (Ed.), Deltas: Models for Exploration. Houston Geol. Soc., 99-150.

Dickinson, W. R., 1970. Interpreting detrital modes of graywacke and arkose. J. Sediment. Petrol., 40:695-707.

1985. Interpreting provenance relations from detrital modes of sandstone. In Zuffa, G. G. (Ed.), Provenance of Arenites. NATO ASI Ser., Ser. C, 148:333-361. 
Dickinson, W. R., Beard, L. S., Brakenridge, G. R., Erjavec, J. L., Ferguson, R. C., Inman, K. F., Knepp, R. A., Lindberg, F. A., and Ryberg, P. T., 1983. Provenance of North American Phanerozoic sandstones in relation to tectonic setting. Geol. Soc. Am. Bull., 94:222-235.

Dolan, J. F., 1989. Eustatic and tectonic controls on deposition of hybrid siliciclastic/carbonate basinal cycles: discussion with examples. AAPG Bull., 73:1233-1246.

Driese, S. G., and Dott, R. H., Jr., 1984. Model for sandstonecarbonate "cyclothems" based on upper member of Morgan Formation (middle Pennsylvanian) of Northern Utah and Colorado. AAPG Bull., 68:574-597.

Elliott, T., 1974. Interdistributary bay sequences and their genesis. Sedimentology, 21:611-622.

1986. Deltas. In Reading, H. D. (Ed.), Sedimentary Environments and Facies (2d ed.): Oxford (Blackwell), 113-154.

Exon, N. F., von Rad, U., and von Stackelberg, U., 1982. The geological development of the passive margins of the Exmouth Plateau off northwest Australia. Mar. Geol., 47:131-152.

Exon, N. F., and Willcox, J. B., 1980. The Exmouth Plateau: stratigraphy, structure and petroleum potential. Bull. Bur. Miner. Resour. Geol. Geophys, Aust., 199:1-52.

Gagliano, S. M., and van Beck, J. L., 1970. Geologic and geomorphic aspects of deltaic processes, Mississippi delta system. In Hydraulic and Geologic Studies of Coastal Louisiana. Cent. for Wetland Resour., Louisiana State Univ., Rep. 1.

Galloway, W. E., 1975. Process framework for describing the morphologic and stratigraphic evolution of deltaic depositional systems. In Broussard, M. L. (Ed.), Deltas: Models for Exploration. Houston Geol. Soc., 87-98.

Gazzi, P., 1966. Le arenarie del flysch sopracretaceo dell'Appennino modenese; correlazioni con il flysch di Monghidoro. Mineral. Petrogr. Acta, 12:69-97.

Handford, C. R., 1985. Facies and bedding sequences in shelf-stormdeposited carbonates-Fayetteville Shale and Pitkin Limestone (Mississippian), Arkansas. J. Sediment. Petrol., 55:123-137.

Haq, B. U., Hardenbol, J., and Vail, P. R., 1987. Chronology of fluctuating sea levels since the Triassic. Science, 235:1155-1167.

Haq, B. U., von Rad, U., O'Connell, S., et al., 1990. Proc. ODP, Init. Repts., 122: College Station, TX (Ocean Drilling Program).

Haq, B. U., von Rad, U., and the ODP Leg 122 Scientific Party, 1988. ODP Leg 122 looks at Exmouth Plateau. Geotimes, 33:10-13.

Ingersoll, R .V., Bullard, T. F., Ford, R. L., Grimm, J. P., Pickle, J. D., and Sares, S. W., 1984. The effect of grain size on detrital modes. A test of the Gazzi-Dickinson point-counting method. $J$. Sediment. Petrol., 54:103-116.

Johnson, H. D., and Baldwin, C. T., 1986. Shallow siliciclastic seas. In Reading, H. G. (Ed.), Sedimentary Environments and Facies (2d ed.): Oxford (Blackwell), 229-282.

Kreisa, R. D., and Bambach, R. K., 1982. The role of storm processes in generating shell beds in Paleozoic shelf environments. In Einsele, G., and Seilacher, A. (Eds.), Cyclic and Event Stratification: Berlin (Springer-Verlag), 200-207.

Kumar, N., and Sanders, J. E., 1976. Characteristics of shoreface storm deposits: modern and ancient examples. J. Sediment. Petrol., 46:145-162.

Ludden, J. N., Gradstein, F. M., et al., 1990. Proc. ODP, Init. Repts., 123: College Station, TX (Ocean Drilling Program).

Mack, G. H., and James, W. C., 1985. Cyclic sedimentation in the mixed siliciclastic-carbonate Abo-Hueco transitional zone (lower Permian), Southwestern New Mexico. J. Sediment. Petrol., 56:635-647.

Matthews, R. K., 1974. Dynamic Stratigraphy: A Introduction to Sedimentation and Stratigraphy: Englewood Cliffs, NJ (PrenticeHall).

Miall, A. D., 1984. Deltas. In Walker, R. G. (Ed.), Facies Models (2d ed.): Geosci. Can. Reprint Ser., 1:105-118.

Moore, R. C., 1964. Paleontological aspects of Kansas, Pennsylvania, and Permian cyclothems. In Merriam, D. F. (Ed.), Symposium on Cyclic Sedimentation. Bull.-Kans. Geol. Surv., 169:287-380.

Mount, J. F., 1984. Mixing of siliciclastic and carbonate sediments in shallow shelf environments. Geology, 12:432-435.

Mutter, J. C., Larson, R. L., and Northwest Australia Study Group, 1989. Extension of the Exmouth Plateau, offshore northwestern
Australia: deep seismic reflection/refraction evidence for simple and pure shear mechanisms. Geology, 17:15-18.

Penland, S., and Boyd, R., 1981. Shoreline changes on the Louisiana barrier coast. IEEE Oceans, 81:209-219.

Penland, S., Suter, J. R., and Moslow, T. F., 1986. Inner-shelf shoal sedimentary facies and sequences: Ship Shoal, northern Gulf of Mexico. In Moslow, T. F., and Rhodes, E. G. (Eds.), Modern and Ancient Shelf Clastics: A Core Workshop. SEPM Core Workshop, 9:73-123.

Prior, D. B., and Suhayda, J. N., 1979. Application on infinite slope analysis to subaqueous sediment instability, Mississippi Delta. Eng. Geol., 14:1-10.

Sarg, J. F., 1988. Carbonate sequence stratigraphy. In Wilgus, C. K., Hastings, B. S., Kendall, C.G.St.C., Posamentier, H. W., Ross, C. A., and Van Wagoner, J. C. (Eds.), Sea-Level Changes: An Integrated Approach. Spec. Publ.-Soc. Econ. Paleontol. Mineral., 42:155-181.

Siedlecka, K., Pickering, K. T., and Edward, M. B., 1989. Upper Proterozoic passive margin deltaic complex, Finnmark, N. Norway. In Whateley, M.K.G., and Pickering, K. T. (Eds.), Deltas: Sites and Traps for Fossil Fuels. Geol. Soc. Spec. Publ. London, 41:205-219.

Specht, R. W., and Brenner, R. L., 1979. Storm-wave genesis of bioclastic carbonates in the Upper Jurassic epicontinental mudstones, east-central Wyoming. J. Sediment. Petrol., 49:1307-1322.

Suttner, L. J., Basu, A., and Mack, G. H., 1981. Climate and the origin of quartz arenites. J. Sediment. Petrol., 51:1235-1246.

Tankard, A. J., and Barwis, J., 1982. Wave-dominated deltaic sedimentation in the Devonian Bokkeveld Basin of South Africa. J. Sediment. Petrol., 52:959-974.

Tucker, M. E., 1981. Sedimentary Petrology An Introduction: Oxford (Blackwell).

Van Wagoner, J. C., Posamentier, H. W., Mitchum, R. M., Vail, P. R., Sarg, J. F., Loutit, T. S., and Hardenbol, J., 1988. An overview of the fundamentals of the sequence stratigraphy and key definitions. In Wilgus, C. K., Hastings, B. S., Kendall, C.G.St.C., Posamentier, H. W., Ross, C. A., and Van Wagoner, J. C. (Eds.), Sea-Level Changes: An Integrated Approach. Spec. Publ.-Soc. Econ. Paleontol. Mineral., 42:39-45.

Veevers, J. J., 1988. Morphotectonics of Australia's northwestern margin: a review. In Purcell, P. G., and Purcell, R. R. (Eds.), The North West Shelf, Australia: Proc. Pet. Expl. Soc. Aust. Symp., 19-27.

von Rad, U., and Exon, N. F., 1983. Mesozoic-Cenozoic sedimentary and volcanic evolution of the starved passive continental margin off northwest Australia. In Watkins, J. S., and Drake, C. L. (Eds.), Studies in Continental Margin Geology: AAPG Mem., 34:253281.

von Rad, U., Thurow, J., Haq, B. U., Gradstein, F., Ludden, J., and ODP Leg 122/123 Shipboard Scientific Parties, 1989. Triassic to Cenozoic evolution of the NW Australian continental margin and the birth of the Indian Ocean (preliminary results of ODP Legs 122 and 123). Geol. Rundsch., 78:1189-1210.

Walker, K. R., Shanmugam, G., and Ruppel, S. C., 1983. A model for carbonate to terrigenous clastic sequences. Geol. Soc. Am. Bull., 94:700-712.

Wright, L. D., 1985. River deltas. In Davis, R. A., Jr. (Ed.), Coastal Sedimentary Environments (2d ed.): New York (Springer-Verlag), $1-76$.

Wright, L. D., and Coleman, J. M., 1974. Mississippi River mouth processes: effluent dynamics and morphologic development. $J$. Geol., 82:751-778.

Yose, L. A., and Heller, P. L., 1989. Sea-level control of mixedcarbonate-siliciclastic, gravity-flow deposition: lower part of the Keeler Canyon Formation (Pennsylvanian), southeastern California. Geol. Soc. Am. Bull., 101:427-439.

Date of initial receipt: 25 May 1990

Date of acceptance: 4 March 1991

Ms 122B-139 
$T_{1}$

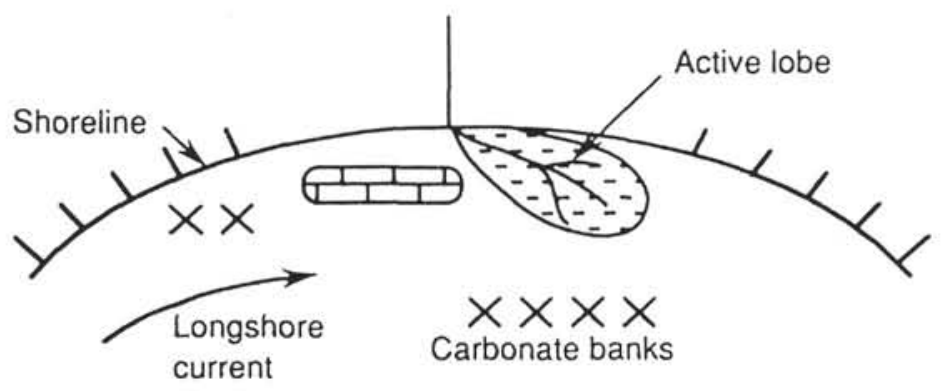

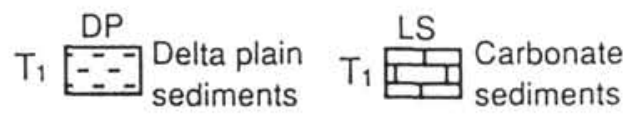

$\mathrm{T} 2$

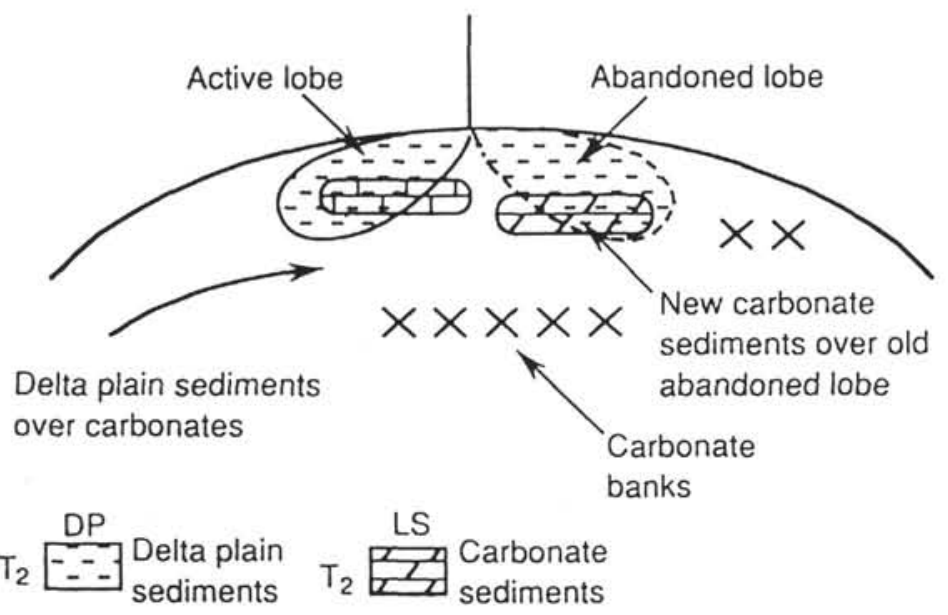

Figure 8. Schematic illustration of the formative processes for the mixed siliciclastic and carbonate cycles in the Upper Triassic deltaic successions. $\mathrm{T} 1=$ time $1, \mathrm{~T} 2=$ time $2, \mathrm{DP}=$ delta plain sediments, $\mathrm{LS}=$ carbonate sediments. 
$1 \mathrm{~cm}$

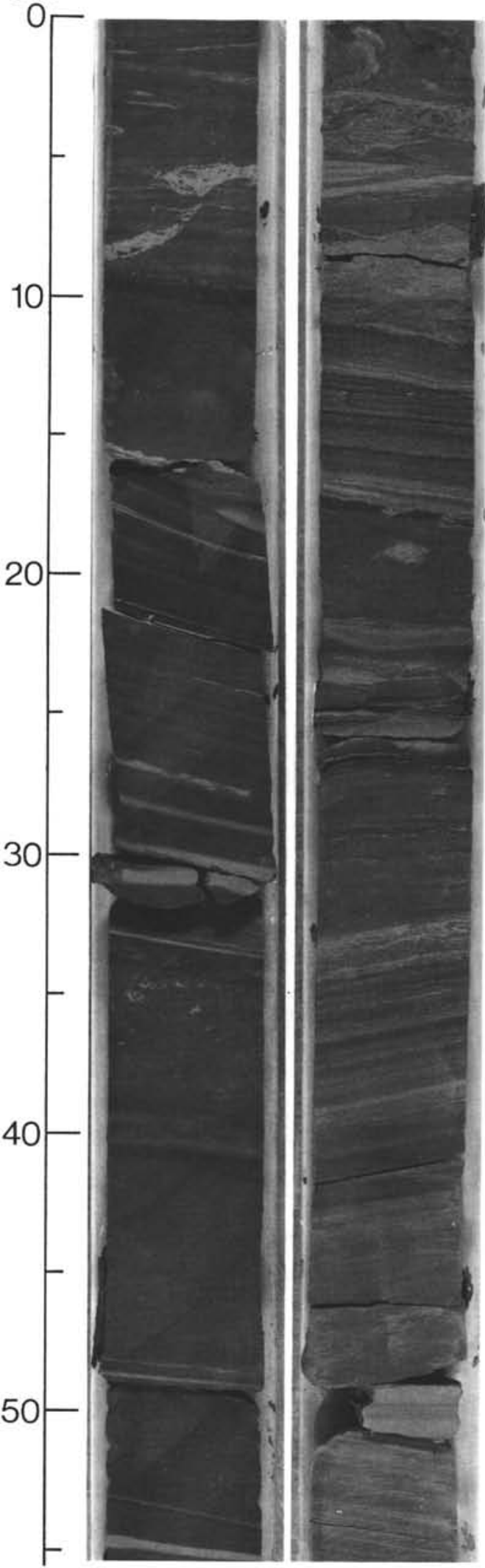

$2 \mathrm{~cm}$

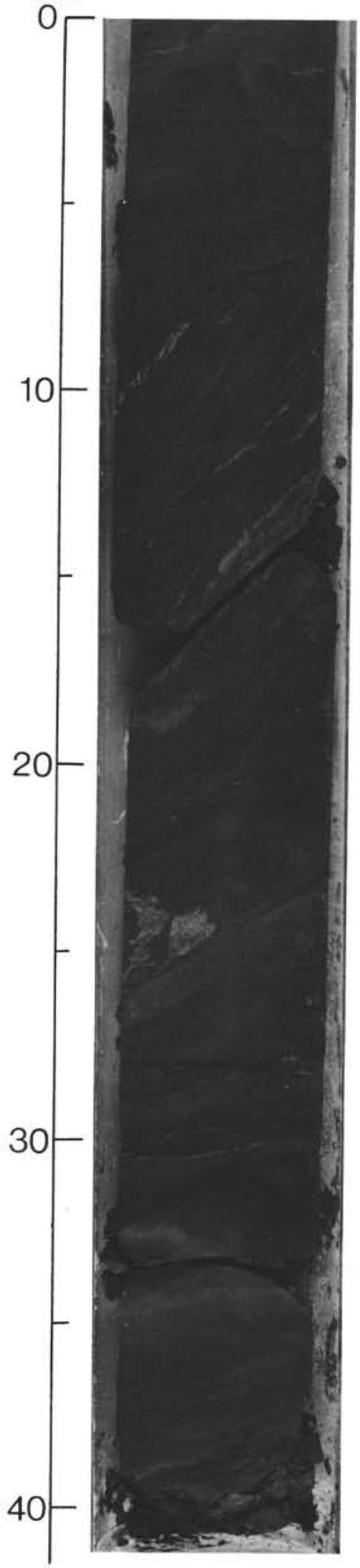

Plate 1. 1. Sections $122-759 \mathrm{~B}-31 \mathrm{R}-2,50-100 \mathrm{~cm}$, (left) and 122-759B-32R-2, 50-100 cm (right). Finely laminated and bioturbated clayey siltstones (left) and ripple-cross laminated siltstones (right) of prodelta deposits. White laminae are sideritic and some burrows are replaced by siderite. 2. Section 122-759B-37R-3, 70-109 cm. Parallel laminated and bioturbated silty claystone with wet deformation structures. 3. Section $122-760 \mathrm{~B}-22 \mathrm{R}-3,60-70 \mathrm{~cm}$. Clayey siltstones interbedded with parallel laminated or ripple cross-laminated silty sandstones of delta front deposits. Water-escape structures are typically developed. 
$3 \mathrm{~cm}$

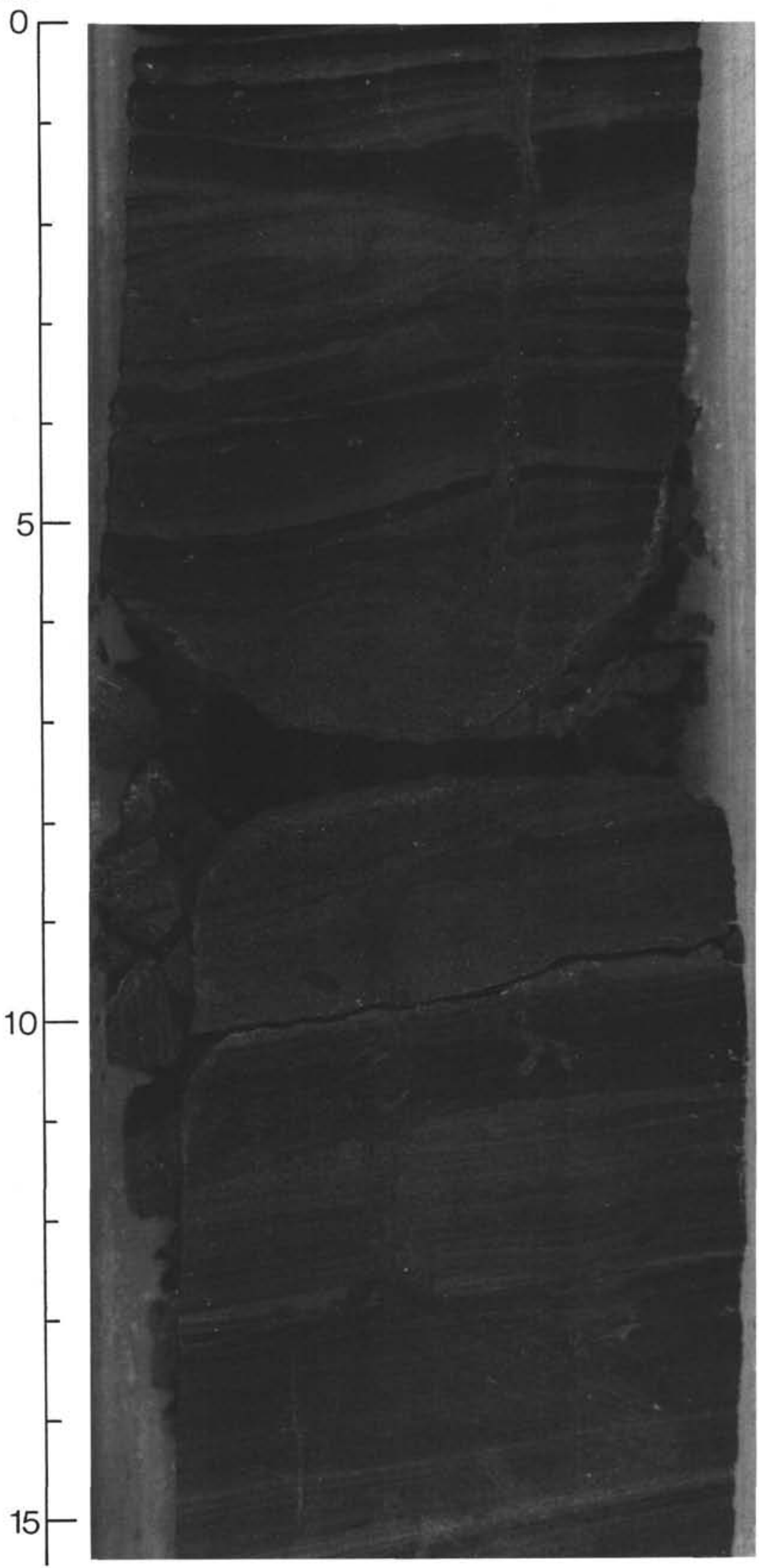

Plate 1 (continued). 

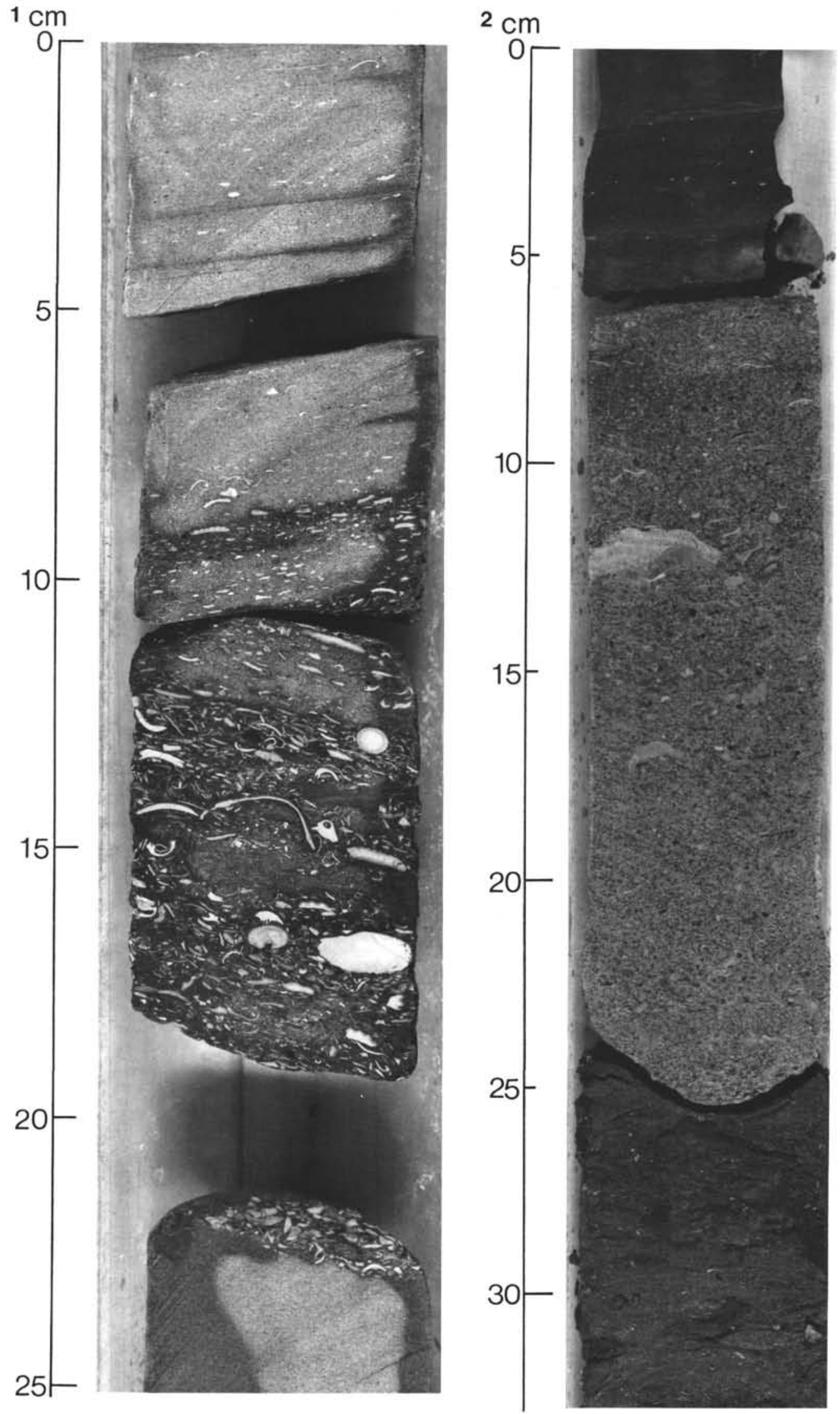

Plate 2. 1. Section 122-759B-16R-1, 24-40 cm. Graded stratified sandstone with many shell fragments, showing packstone in the basal part. 2. Section 122-760B-9R-2, 20-50 cm. Bioturbated silty claystone interbedded with graded grainstone with an erosional base. 3. Sections $122-760 \mathrm{~A}-33 \mathrm{X}-3$ to $122-760 \mathrm{~A}-$ $33 \mathrm{X}$-CC. Fine- to very fine-grained sandstones characterized by parallel laminations and ripple cross-laminations. 4 . Section $122-760 \mathrm{~B}-22 \mathrm{R}-2,55-90 \mathrm{~cm}$. Sandy siltstones with many coal layers, algal stringers, and rootlets. 
UPPER TRIASSIC SILICICLASTIC-CARBONATE CYCLES
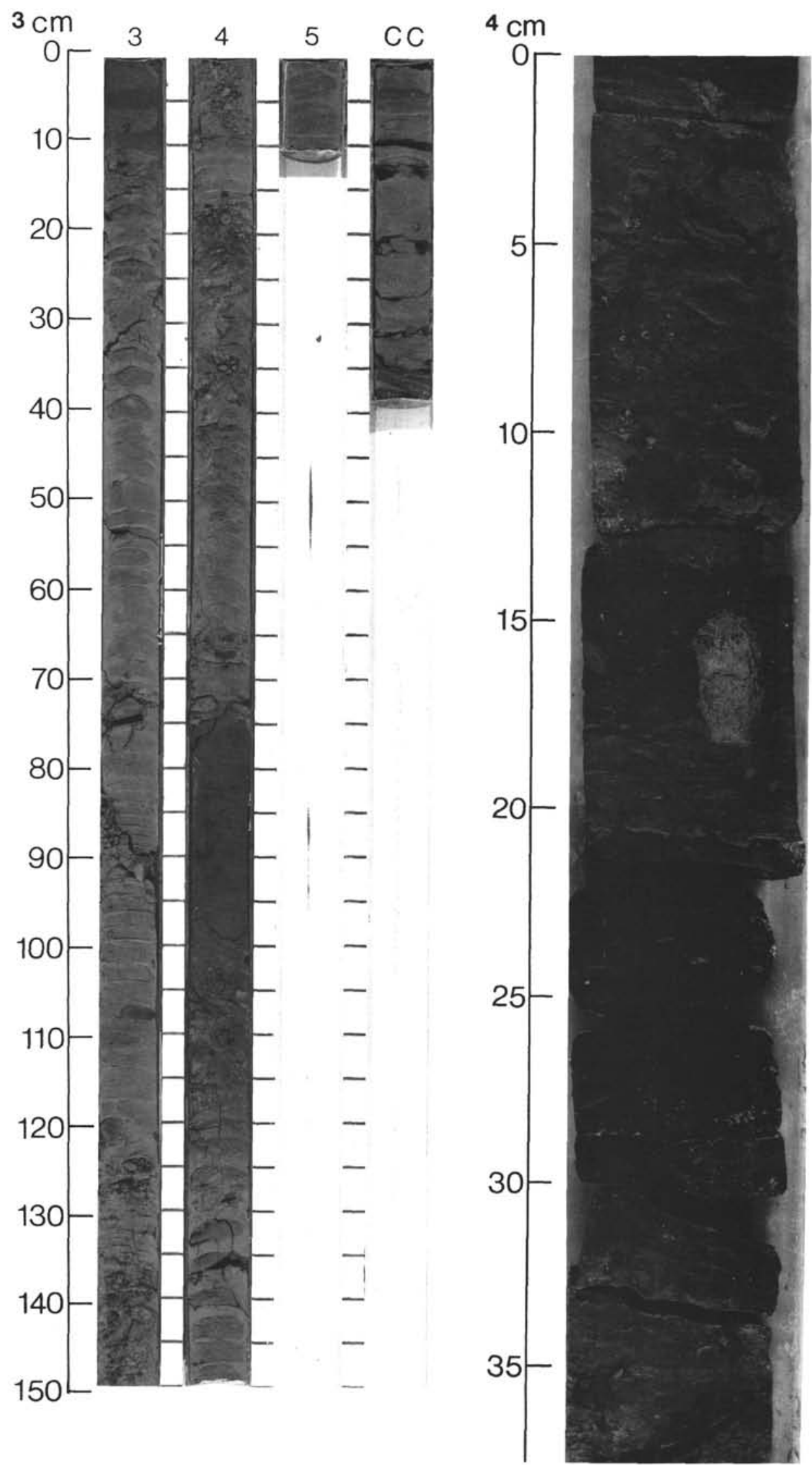

Plate 2 (continued). 

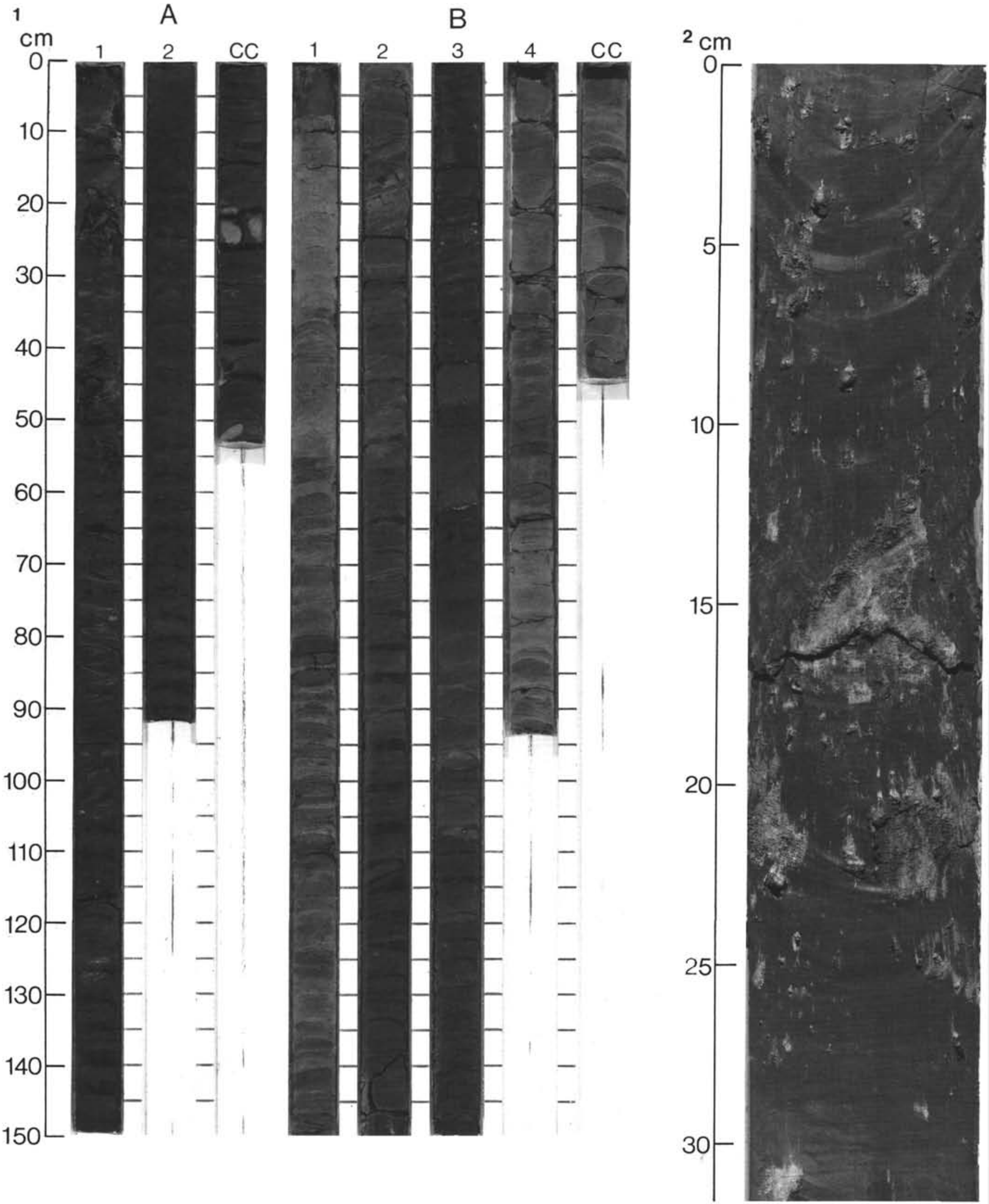

Plate 3. 1. Sections $122-760 \mathrm{~A}-27 \mathrm{X}-1$ to $122-760 \mathrm{~A}-27 \mathrm{X}-\mathrm{CC}$ (A) and $122-760 \mathrm{~A}-28 \mathrm{X}-1$ to $122-760 \mathrm{~A}-28 \mathrm{X}-\mathrm{CC}$ (B). Two major fining-upward sequences from cross-laminated sandstone (Sections 122-760A-28X-4 and 122-760A-28X-1) to parallel or cross-laminated claystones with some sandstone intercalations (Sections 122-760A-28X-2, 122-760A-28X-3, and 122-760A-27X-1 to 122-760A-27X-CC), showing distributary channel deposits. 2. Section $122-760 \mathrm{~A}-16 \mathrm{X}-2,75-105 \mathrm{~cm}$. Silty claystone with many carbonate concretions, showing paleosol profiles developed in distributary bay deposits. 

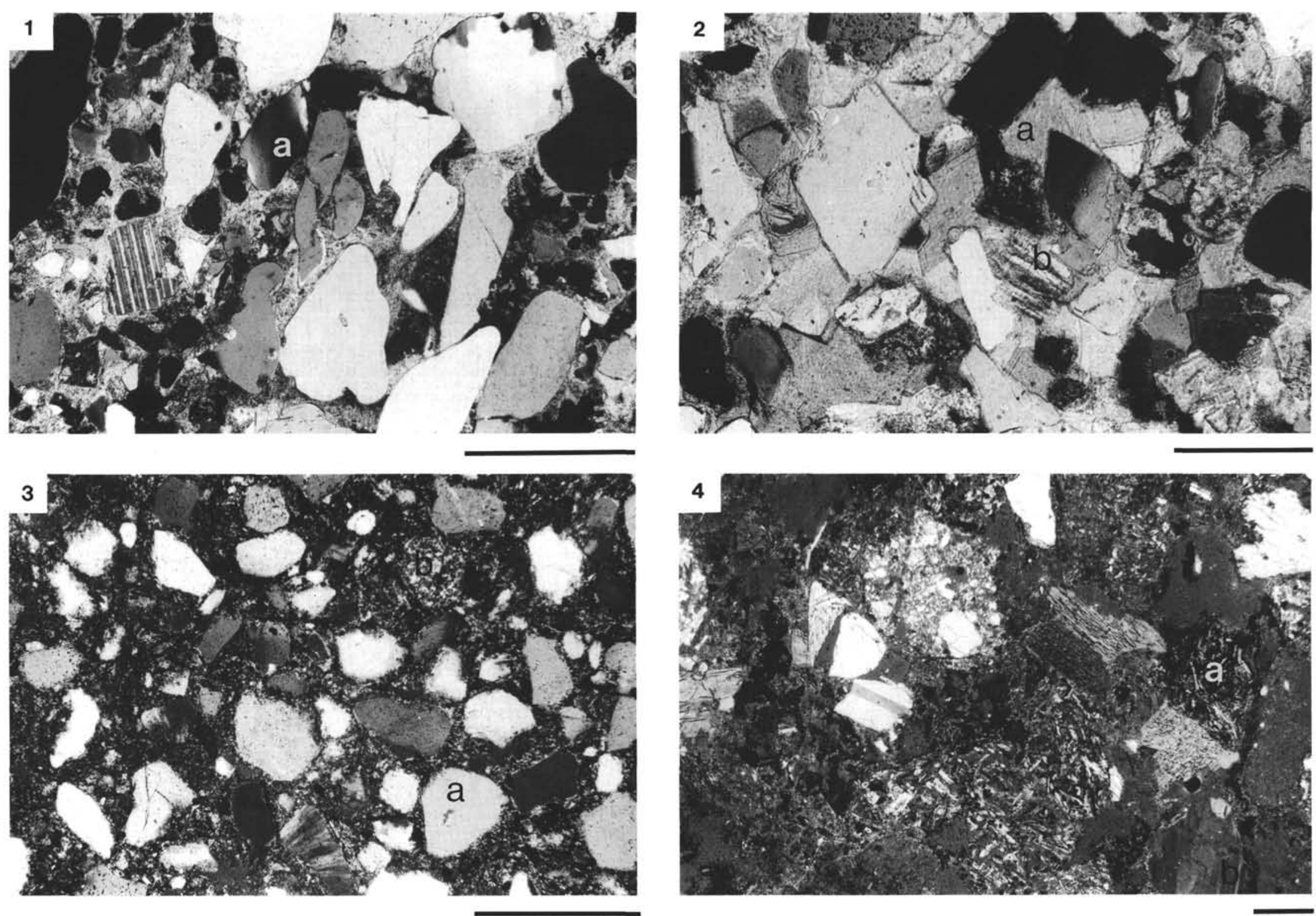

Plate 4. Photographs of the Upper Triassic sandstones. Scale is $0.2 \mathrm{~mm}$. 1. Sample 122-759B-11R-2, 12-19 cm. Quartzose sandstone characterized by rounded quartz grains. Some quartz grains show undulatory extinction (a) and the others have straight extinction. 2. Sample 122-760A-31X-3, 129-131 cm. Matrix (a) and some plagioclase grains (b) have been replaced by carbonate. 3. Sample $122-760 \mathrm{~A}-26 \mathrm{X}-2,112-115 \mathrm{~cm}$. Quartzose sandstones with subangular quartz showing straight extinction (a) and some polycrystalline quartzose grains (b). 4. Sample 122-760B-20R-4, 24-26 cm. Volcanogenic sandstone with many volcanic rock fragments (a) and plagioclase grains (b). 


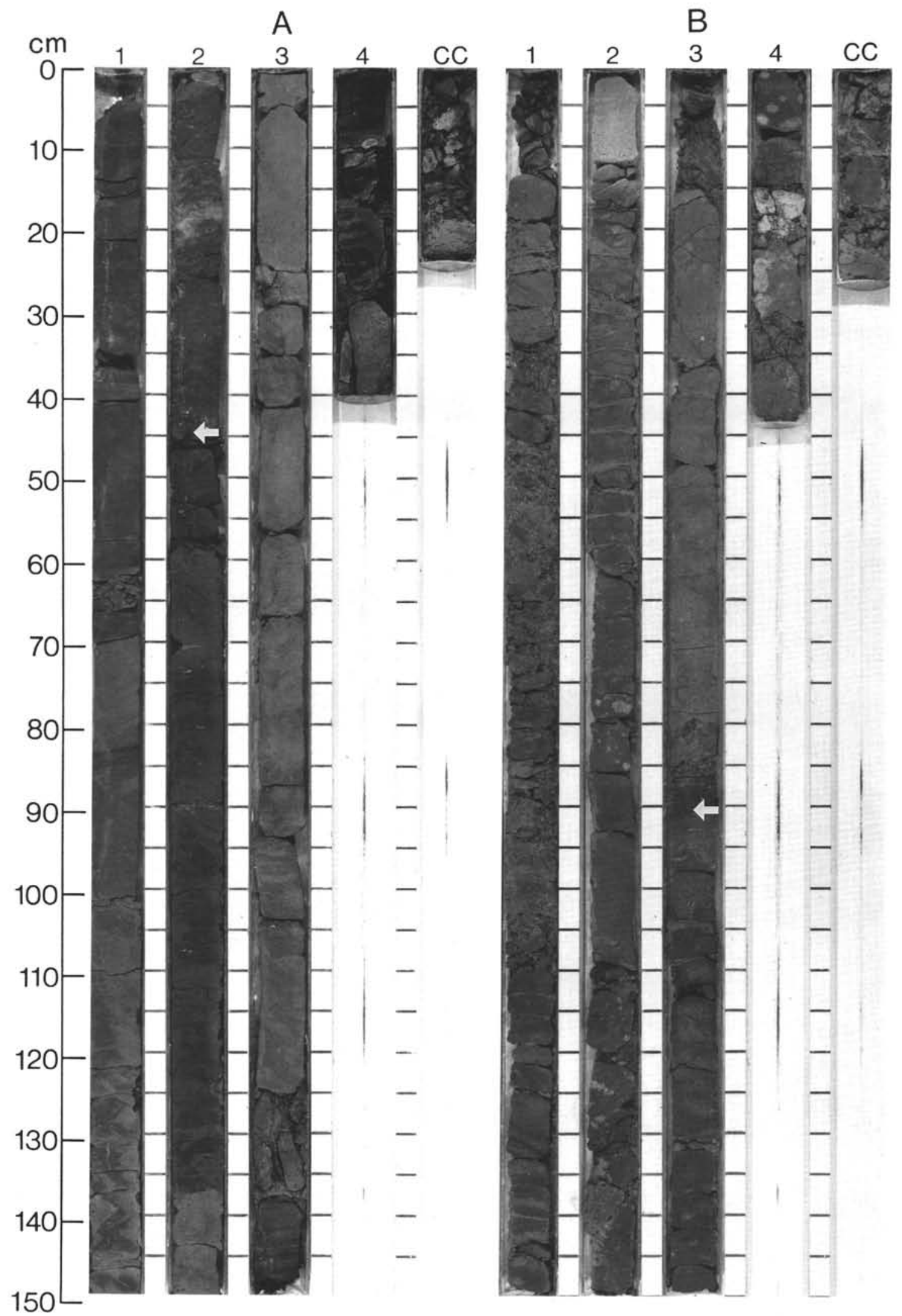

Plate 5. Arrows indicating fossiliferous siltstones in Sections 122-759B-20R-1 to 122-759B-20R-CC (A) and conglomerate in Sections 122-760B-11R-1 to 130-760B-11R-CC) (B) developed at the basal part of delta front deposits. 